\title{
A New Intra-Specific and High-Resolution Genetic Map of Eggplant Based on a RIL Population, and Location of QTLs Related to Plant Anthocyanin Pigmentation and Seed Vigour
}

\author{
Laura Toppino $^{1}\left(\mathbb{D}\right.$, Lorenzo Barchi ${ }^{2, *}$, Francesco Mercati ${ }^{3} \mathbb{D}$, Nazzareno Acciarri ${ }^{4}$, \\ Domenico Perrone $^{5,6}$, Matteo Martina ${ }^{2}{ }^{(D}$, Stefano Gattolin ${ }^{7}\left(\mathbb{D}\right.$, Tea Sala ${ }^{1}\left(\mathbb{D}\right.$, Stefano Fadda ${ }^{1}$, \\ Antonio Mauceri ${ }^{8}$, Tommaso Ciriaci ${ }^{4}$, Francesco Carimi ${ }^{3}$ (D), Ezio Portis ${ }^{2}$ (D), \\ Francesco Sunseri ${ }^{8}\left(\mathbb{D}\right.$, Sergio Lanteri ${ }^{2}$ and Giuseppe Leonardo Rotino ${ }^{1}$ (D) \\ 1 CREA, Research Centre for Genomics and Bioinformatics, 26836 Montanaso Lombardo (LO), Italy; \\ laura.toppino@crea.gov.it (L.T.); tea.sala@crea.gov.it (T.S.); stefano.fadda@crea.gov.it (S.F.); \\ giuseppeleonardo.rotino@crea.gov.it (G.L.R.) \\ 2 DISAFA-Plant genetics and breeding-University of Turin, 10095 Grugliasco (TO), Italy; \\ matteo.martina@unito.it (M.M.); ezio.portis@unito.it (E.P.); sergio.lanteri@unito.it (S.L.) \\ 3 Institute of Biosciences and BioResources, Division of Palermo-National Research Council (CNR), \\ 90129 Palermo, Italy; francesco.mercati@ibbr.cnr.it (F.M.); francesco.carimi@ibbr.cnr.it (F.C.) \\ 4 CREA, Research Centre for Vegetable and Ornamental Crops, 63030 Monsampolo del Tronto (AP), Italy; \\ acciarri@libero.it (N.A.); t.ciriaci@libero.it (T.C.) \\ 5 CREA, Research Centre for Vegetable and Ornamental Crops, 84098 Pontecagnano (SA), Italy; \\ domenico.perrone@crea.gov.it \\ 6 CREA, Research Centre for Plant Protection and Certification, 84091 Battipaglia, Italy \\ 7 Institute of Agricultural Biology and Biotechnology (IBBA)-National Research Council (CNR), \\ 20133 Milano, Italy; stefano.gattolin@ibba.cnr.it \\ 8 Department AGRARIA, University Mediterranea of Reggio Calabria, 89124 Reggio Calabria, Italy; \\ antonio.mauceri87@unirc.it (A.M.); francesco.sunseri@unirc.it (F.S.) \\ * Correspondence: lorenzo.barchi@unito.it
}

Received: 8 June 2020; Accepted: 2 July 2020; Published: 4 July 2020

\begin{abstract}
Eggplant is the second most important solanaceous berry-producing crop after tomato. Despite mapping studies based on bi-parental progenies and GWAS approaches having been performed, an eggplant intraspecific high-resolution map is still lacking. We developed a RIL population from the intraspecific cross ' $305 \mathrm{E} 40$ ', (androgenetic introgressed line carrying the locus Rfo-Sa1 conferring Fusarium resistance) x ' $67 / 3$ ' (breeding line whose genome sequence was recently released). One hundred and sixty-three RILs were genotyped by a genotype-by-sequencing (GBS) approach, which allowed us to identify 10,361 polymorphic sites. Overall, $267 \mathrm{~Gb}$ of sequencing data were generated and $\sim 773 \mathrm{M}$ Illumina paired end (PE) reads were mapped against the reference sequence. A new linkage map was developed, including 7249 SNPs assigned to the 12 chromosomes and spanning $2169.23 \mathrm{cM}$, with iaci@liberoan average distance of $0.4 \mathrm{cM}$ between adjacent markers. This was used to elucidate the genetic bases of seven traits related to anthocyanin content in different organs recorded in three locations as well as seed vigor. Overall, from 7 to 17 QTLs (at least one major QTL) were identified for each trait. These results demonstrate that our newly developed map supplies valuable information for QTL fine mapping, candidate gene identification, and the development of molecular markers for marker assisted selection (MAS) of favorable alleles.
\end{abstract}

Keywords: linkage map; RAD; QTL; Solanum melongena 


\section{Introduction}

Eggplant (Solanum melongena $\mathrm{L} ., 2 \mathrm{n}=2 \mathrm{x}=24$ ) is a member of the Solanaceae, a large plant family comprising over 3000 species and including important crops such as tomato, potato, pepper and tobacco. Unlike most of the other solanaceous crops, which are native to the New World [1-3], eggplant has a phylogenetic uniqueness due to its exclusive Asian origin [4]. It has been reported that the species resulted from two or three independent domestication events [5,6], although a recent study suggested a single domestication event [7]. Eggplant worldwide production is estimated as about $54 \mathrm{Mt}$, with China, India and Indonesia being the major producing countries, while Egypt, Turkey and Italy represent the main producers in the Mediterranean region (FAO 2018; [8]). Breeding efforts in eggplant, like in most crops, have been focused on increasing yield, resistance/tolerance to biotic and abiotic stress, and fruit shelf-life, but also on improving some plant morphological distinguishing traits (reduced prickliness and leaf hairiness) as well as raising the content of health-promoting metabolites (e.g., anthocyanins and chlorogenic acid) or reducing the anti-nutritional content (e.g., steroidal glycoalkaloid, saponins) in the berries. Furthermore, studies have been carried out with the goal to improve seed germination and seedling emergence [9-11], which affect the crop performance.

In eggplant, several inter-specific genetic maps were developed by applying pre-next generation sequencing (NGS) techniques (RFLP, AFLP, RAPD, SSR, etc.). They were based on inter-specific crosses between cultivated S. melongena and S. linnaeanum (=S. sodomaeum) or S. incanum and used for Quantitative Trait Loci (QTL) analyses of domestication and morphological traits [12-16], as well as to locate genes involved in polyphenol biosynthesis [17] and resistance to Verticillium spp. [18]. Intra-specific maps were also built [19-22] and, more recently, Fukuoka et al. [23] generated two intra-specific genetic maps based on $\mathrm{F}_{2}$ populations, which were then combined into one on the basis of common markers for studying macro-syntenic relationships between eggplant and tomato, as well as for QTL analysis of parthenocarpy [24] and resistance to Fusarium oxysporum [25].

The advent of NGS-based marker technologies, by increasing the speed, throughput, and cost effectiveness of genotyping and providing genome-wide marker coverage, has allowed the development of the so-called 'second generation' maps. Barchi et al. [26], by applying the RAD-seq protocol from Baird et al. [27] on an intra-specific $\mathrm{F}_{2}$ population, identified 10,000 single nucleotide polymorphisms (SNPs) as well as nearly 1000 polymorphic indels, and more than 2000 SNPs were found of potential use for genotyping on the basis of a GoldenGate $(\subset$ assay. Afterwards, the first 'second generation genetic map' was developed [28], which included 415 markers assigned to the 12 chromosomes. The latter was used to identify the genetic bases of traits associated with anthocyanin content [28] and, more recently, for detecting QTL affecting key horticultural traits [29], fruit metabolic content [30] and resistance to soil-borne diseases [31]. Furthermore, the previously identified loci were validated, and new linked marker/trait associations were detected, through a genome-wide association (GWA) mapping approach [32,33]. Second generation intra-specific genetic maps were also generated [2] for anchoring the first draft genome sequence of eggplant and for mapping resistance QTLs to Ralstonia strains by SNPs developed through Illumina sequencing of the parents of a Recombinant inbreed line (RIL) mapping population as well as AFLP, SSR and SRAP markers [34].

Despite recent efforts, the linkage maps used for identifying the genetic basis of traits of breeding interest are still not saturated, hampering the fine mapping of QTL regions and the identification of candidate genes associated with the phenotypic traits. Up to now, the only available high-resolution SNP-based linkage map was developed on a $F_{2}$ population from the inter-specific cross (S. melongena $\times$ S. linneanum) and was employed to highlight QTLs affecting stem height and fruit and leaf morphology [35].

We previously developed a RIL mapping population of $170 \mathrm{~F}_{6}-\mathrm{F}_{7}$ lines from the intra-specific cross between the breeding lines ' $305 \mathrm{E} 40$ ' (female parent) and ' $67 / 3$ ' (male parent). Furthermore, the first high quality eggplant genome sequence of the breeding line ' $67 / 3$ ' was released [36] and, through the resequencing of the female parent ('305E40') and a low coverage Illumina sequencing of each RIL, we constructed a first linkage map aimed at anchoring the scaffolds to the 12 chromosomes. 
The map also demonstrated efficient mapping metabolomic traits of interest related to the metabolomics composition of fruit flesh and peel [37].

The genetic basis of anthocyanin synthesis and accumulation has been widely studied in the Solanaceae [38-43]. In the last decade, QTL-related studies using family-based or GWA mapping approaches allowed us to shed light on the genetic bases of anthocyanin distribution in eggplant as well as to identify its syntenic relationships with tomato $[28,30,32,44]$. By contrast, no information is available on QTLs controlling seed vigor in term of speed of seedling emergence, which diversifies the parents of our RIL mapping population. Here, we propose a more breeder-friendly map developed through a genotype-by-sequencing (GBS) approach with our RIL mapping population, whose reliability for mapping studies has been proved by identifying QTLs related to plant anthocyanin pigmentation and seed vigor.

\section{Materials and Methods}

\subsection{Plant Material}

A population of $163 \mathrm{~F}_{7}$ plants, previously obtained by the single seed descent approach from a cross between eggplant lines ' $305 \mathrm{E} 40$ ' and ' $67 / 3$ ' [28,36], was employed. The two parental lines were contrasting for a wide number of key agronomic and metabolic traits [28-31], as well as for their seed vigor. The '305E40' line (female parent) is a double haploid derived from the inter-specific somatic hybrid [Solanum aethiopicum gr. gilo(+)S. melongena cv. Dourga], which was repeatedly backcrossed with the recurrent eggplant genotypes (lines DR2 and Tal1/1) prior to selfing and anther culture. This line carries the locus Rfo-sa1 from S. aethiopicum, which confers complete resistance to the soil-borne fungus Fusarium oxysporum $f$. sp. melongenae (Fom) [45] and is partially resistant to Verticillium dahliae [31]. Plants of '305E40' display a slight anthocyanin overall pigmentation, produces pink flowers and long, highly pigmented dark purple fruits characterized by the presence of the anthocyanin delphinidin-3-rutinoside (D3R) as well as a higher glycoalkaloids and organic acid content than the ones of ' $67 / 3$ ' [28-30]. The ' $67 / 3$ ' line is an F8 selection from the intra-specific cross cv. 'Purpura' $\times \mathrm{cv}$. 'CIN2', which lacks the Rfo-sa1 locus and is fully susceptible to Verticillium [31]. Its plants display higher anthocyanin pigmentation than '305E40' in leaves and stems and produce violet flowers and round, violet colored fruits with white peel colour both under and next to the calyx. The fruits are characterized by the presence of the anthocyanin nasunin in the peel, higher soluble solids, sugars and chlorogenic acid content in the flesh compared to 305E40.

The mapping population was sown, along with both parents and the $F_{1}$ hybrid, in glasshouses at Montanaso Lombardo in 2012. The seeds were sown in plastic trays consisting of 104 holes (8 rows of 13 holes each) filled with peat and placed over an electric warmed carpet at $24^{\circ} \mathrm{C}$. For each RIL, we sowed 52 seeds split in two replicates of 26 seeds. Each replicate was sown in two adjacent randomly chosen rows containing 13 holes of the replicate-specific tray, using a single seed per hole; each replicate was kept under the same conditions but in a different glasshouse at Montanaso Lombardo. All plantlets were grown in heated glasshouses (minimum temperature of $15^{\circ} \mathrm{C}$ ensured) until the 3rd-4th leaf, and then were transplanted in three field trials in northern (Montanaso Lombardo, ML, $45^{\circ} 20^{\prime} \mathrm{N}, 9^{\circ} 26^{\prime} \mathrm{E}$ ), central (Monsampolo del Tronto, MT, $42^{\circ} 53^{\prime} \mathrm{N}, 13^{\circ} 47^{\prime} \mathrm{E}$ ) and southern (Battipaglia, $\left.\mathrm{BP}, 40^{\circ} 36^{\prime} \mathrm{N}, 14^{\circ} 59^{\prime} \mathrm{E}\right)$ Italy. Mulched twin rows of $1.1 \mathrm{~m}$ width were arranged using plastic black PE $(0.05 \mathrm{~mm})$, and plantlets were transplanted at $45 \mathrm{~cm}$ between each other along the rows. A drip irrigation system was employed for watering and fertilizing, and local standard horticultural practices were applied. In each site, the material was transplanted in the field according to a randomized block design (3 replicate blocks, 4 plants per block) to score the phenotypic traits.

\subsection{Library Construction and Sequencing}

DNA from the RIL population, parental lines and $F_{1}$ hybrid was extracted following a modified CTAB method [46] as indicated elsewhere [47]. Library construction was performed 
as proposed by Acquadro et al. [48] by using a HindIII-MseI enzyme combination and adding a final biotin/streptavidin-coated beads-based purification step. Quality, quantity and reproducibility of libraries were assessed with a Bioanalyzer instrument (DNA High Sensitivity chip) as well as qPCR using KAPA SYBR FAST Universal 2X qPCR Master Mix (Kapa Biosystems, Boston, MA, USA). On the basis of the quantitation, DNA libraries were pooled and sequenced on Illumina HiSeq 2500 platform (Illumina Inc., San Diego, CA, USA), following the manufacturer protocol using 150 PE chemistry at Biodiversa srl (Rovereto (TN), Italy).

\subsection{Sequence Analysis and Map Construction}

Raw reads were analyzed with Scythe (https://github.com/vsbuffalo/scythe) for filtering out contaminant substrings, and Sickle (https://github.com/najoshi/sickle), for removing reads with poor quality ends $(\mathrm{Q}<30)$. Illumina reads were de-multiplexed on the basis of the Illumina TruSeq index using Stacks process rad tags. Alignment to the reference eggplant genome [36] was carried out using the Burrows-Wheeler Aligner (BWA) aligner [49] (i.e., mem command) with default parameters and avoiding multiple-mapping reads. BAM files were processed and use for the SNP calling using bcftools mpileup/call/norm utilities [50] with default parameters, except for the use of multiallelic calling model (-m option), minimum mapping quality $(\mathrm{Q}=20)$ and filtering out multimapping events $(-\mathrm{q}>1)$. Only SNPs with at most $20 \%$ of missing data and a mean-minDP of 20 were retained for linkage analyses. Polymorphic markers were grouped in linkage groups with "R/qtl" package [51], with minimum $\mathrm{LOD}=8$, rec $\leq 0.15$. For each linkage group identified, identical loci were removed with the Exclude identical function and the remaining loci were ordered with Joinmap software (version 4, [52]), using a LOD of 8 and the Kosambi function to estimate distance and the Maximum-likelihood function to infer correct order. Markers exhibiting segregation distortion were identified applying the chi-square $\left(X^{2}\right)$-goodness-of-fit test $(p<0.001)$ and also integrated into the map. The ordering step was iterated several times, each time by correcting genotype calls with the "SMOOTH.pl" script, which is a Perl implementation of the SMOOTH software, as developed by van Os et al. [53]. Finally, visual inspection of genotypes was applied to identify and correct the remaining genotype errors. Linkage groups were visualized in MapChart (version 2.32, [54]).

\subsection{Phenotypic Traits Evaluation}

The speed of emergence and hypocotyl anthocyanin distribution traits were assessed on 56 plantlets of each RIL, of the two parental lines and their $\mathrm{F}_{1}$ hybrids, which were obtained from as many seeds sown as previously described in Plant material.

The speed of emergence index (sei) was evaluated as the time, expressed in days, needed for the emergence of $50 \%+1$ plantlets from the soil. Hypocotyl anthocyanin (hyan) trait was assessed on plantlets at the second-third leaf stage (Figure $1 \mathrm{~d}$ ) according to a $0-5$ scale, with " 0 " representing no visible anthocyanin coloration (i.e., completely green tissues) and " 5 " representing complete dark violet coloration. 


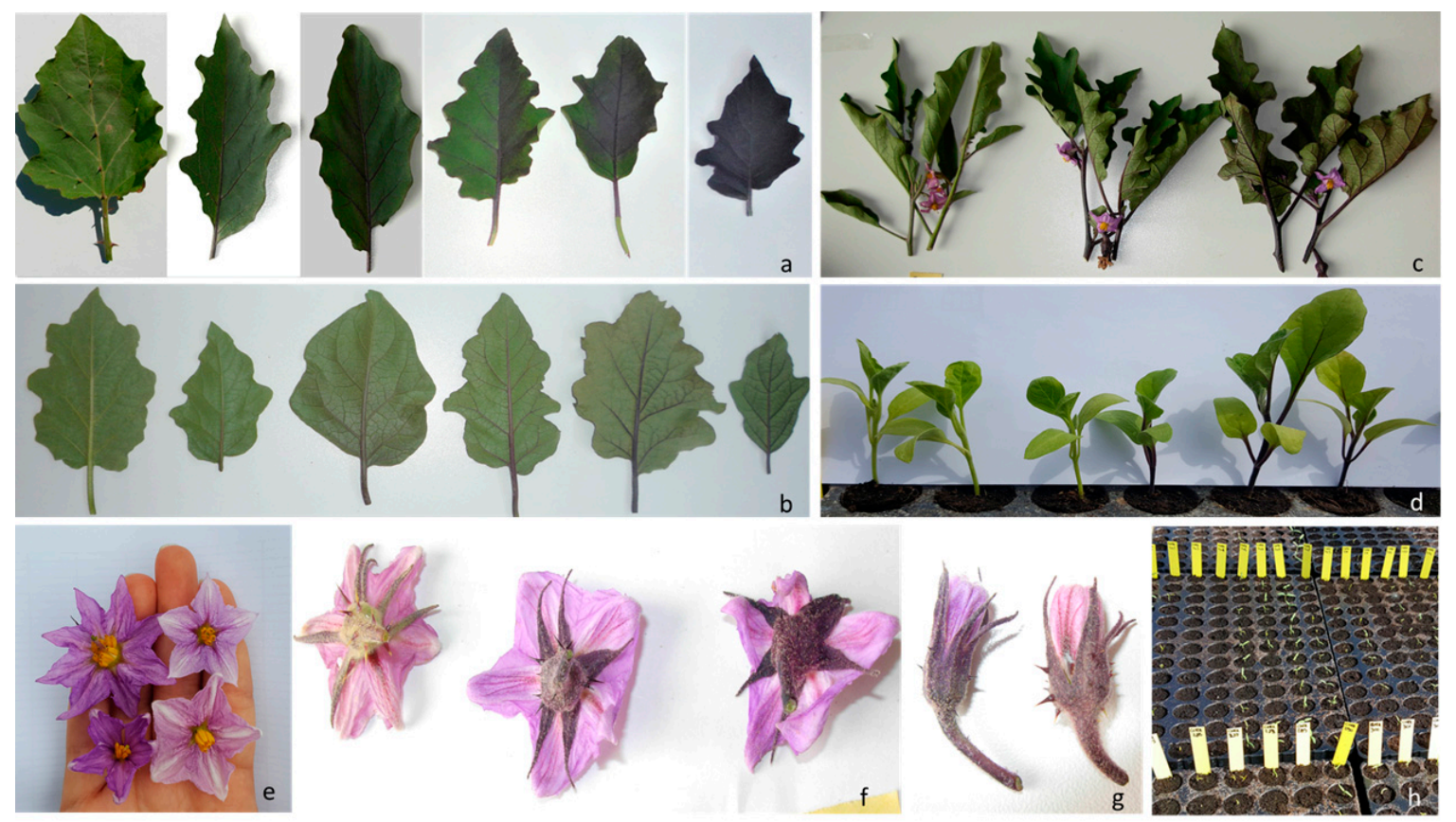

Figure 1. Phenotypic trait evaluation. (a) adlan (range from 0 to 5); (b) lvean (0-5); (c) stean $(1,3,5) ;(\mathbf{d})$ hyan $(0,5) ;(\mathbf{e})$ corcol (clockwise from top-right: light violet, light pink, dark pink, dark violet); (f) flian $(1,3,5) ;(\mathbf{g})$ toan (violet-reddish); (h) sei (picture at 10 days after sowing).

In all the three field trials (ML, MT and BT), the material was arranged as a set of three randomized complete blocks with 4 replicate plants per entry per block. Phenotyping was based on the European Cooperative program for Plant Genetic Resource descriptors panel for Solanaceae (ECPGR, 2008) and the International Board for Plant Genetic Resource descriptors for eggplant (IBPGR, 1990). The traits assayed, reported in Figure 1 and detailed in Table 1, were: adaxial leaf lamina anthocyanin (adlan), corolla colour (corcol), flower anthocyanin intensity (flian), hypocotyl anthocyanin (hyan), leaf venation anthocyanin (lvean), stem anthocyanin (stean), anthocyanin tonality (toan).

The anthocyanin content of stems, leaves and flower calyxes was scored on a 0 (no visible coloration) to 5 (complete dark violet coloration) scale. Anthocyanin content in leaves and leaf venation was evaluated on 4 leaves per RIL in each block, chosen in the upper middle part of the plant. Stem anthocyanin content was measured as an average value based on 3 stems per block. Flower anthocyanin intensity resulted from averaging 5 flowers per block. Anthocyanin tonality was scored as " 1 " reddish, " 3 " intermediate, or " 5 " violet. Finally, for the corolla colour, the trait was coded as " 1 ", pink; " 2 ", dark pink; "3", light violet; "4", violet-pink and " 5 ", violet. 
Table 1. List of the traits analyzed and their code, means, standard deviations (SD), coefficients of variation (cv), broad sense heritability and transgressive genotypes for the traits in study.

\begin{tabular}{|c|c|c|c|c|c|c|c|c|c|c|c|c|c|c|c|c|c|c|c|}
\hline Trait & $\begin{array}{l}\text { Trait } \\
\text { Code }\end{array}$ & $\begin{array}{c}305 \mathrm{E} 40 \\
\text { Mean }\end{array}$ & $\pm \mathrm{SD}$ & $\begin{array}{c}67 / 3 \\
\text { Mean }\end{array}$ & $\pm \mathrm{SD}$ & $\begin{array}{c}\text { F1 } \\
\text { Mean }\end{array}$ & $\pm \mathrm{SD}$ & cv & $\begin{array}{l}\text { RIL pop } \\
\text { Means }\end{array}$ & $\pm \mathrm{SD}$ & $\mathrm{cv}$ & Shapiro-Wilks & Skewness & SE & Kurtosis & SE & Heritability & $\begin{array}{c}\text { Transgressive } \\
\text { Respect 305E40 }\end{array}$ & $\begin{array}{l}\text { Transgressive } \\
\text { Respect } 67 / 3\end{array}$ \\
\hline \multirow{3}{*}{$\begin{array}{l}\text { Adaxial Leaf } \\
\text { Lamina } \\
\text { Anthocyanin }\end{array}$} & adlan_BT & 0.42 & 0.20 & 5.00 & 0.00 & 1.67 & 1.17 & 0.70 & 1.76 & 1.58 & 0.89 & 0.87 & 0.72 & 0.08 & -0.75 & 0.16 & 0.97 & 2 & 0 \\
\hline & adlan_ML & 0.42 & 0.20 & 4.67 & 0.41 & 2.25 & 0.42 & 0.19 & 2.04 & 1.58 & 0.77 & 0.90 & 0.43 & 0.08 & -1.15 & 0.16 & 0.94 & 0 & 0 \\
\hline & adlan_MT & 0.00 & 0.00 & 2.67 & 0.87 & 1.11 & 0.60 & 0.54 & 0.69 & 1.03 & 1.49 & 0.71 & 1.63 & 0.07 & 2.14 & 0.13 & 0.92 & 0 & 0 \\
\hline \multirow{3}{*}{$\begin{array}{c}\text { Stem } \\
\text { Anthocyanin }\end{array}$} & stean_BT & 2.17 & 0.25 & 5.00 & 0.00 & 4.83 & 0.25 & 0.05 & 3.80 & 1.02 & 0.27 & 0.92 & -0.62 & 0.07 & -0.14 & 0.13 & 0.96 & 3 & 0 \\
\hline & stean_ML & 2.33 & 0.43 & 5.00 & 0.00 & 4.78 & 0.36 & 0.08 & 3.80 & 0.98 & 0.26 & 0.92 & -0.35 & 0.07 & -0.80 & 0.13 & 0.96 & 0 & 0 \\
\hline & stean_MT & 1.11 & 0.33 & 4.89 & 0.33 & 4.44 & 0.53 & 0.12 & 3.39 & 1.08 & 0.32 & 0.91 & -0.22 & 0.07 & -0.53 & 0.13 & 0.95 & 0 & 0 \\
\hline \multirow{3}{*}{$\begin{array}{l}\text { Leaf Venation } \\
\text { Anthocyanin }\end{array}$} & lvean_BT & 1.67 & 0.26 & 5.00 & 0.00 & 4.33 & 0.26 & 0.06 & 3.61 & 1.33 & 0.37 & 0.76 & 4.26 & 0.08 & 71.86 & 0.16 & 0.86 & 1 & 0 \\
\hline & lvean_ML & 2.75 & 0.42 & 4.92 & 0.20 & 4.75 & 0.27 & 0.06 & 3.74 & 0.99 & 0.27 & 0.92 & -0.54 & 0.08 & -0.24 & 0.16 & 0.87 & 2 & 0 \\
\hline & lvean_MT & 1.00 & 0.71 & 4.22 & 0.97 & 4.44 & 1.01 & 0.23 & 3.06 & 1.53 & 0.50 & 0.91 & -0.38 & 0.07 & -0.95 & 0.13 & 0.87 & 0 & 0 \\
\hline \multirow{3}{*}{$\begin{array}{l}\text { Anthocyanin } \\
\text { Intensity }\end{array}$} & flian_BT & 2.28 & 1.12 & 5.00 & 0.00 & 4.89 & 0.22 & 0.05 & 4.27 & 0.89 & 0.21 & 0.79 & -1.05 & 0.07 & 0.40 & 0.13 & 0.94 & 0 & 0 \\
\hline & flian_ML & 2.89 & 0.89 & 4.89 & 0.33 & 4.67 & 0.43 & 0.09 & 3.95 & 1.06 & 0.27 & 0.83 & -0.75 & 0.07 & -0.06 & 0.13 & 0.95 & 0 & 0 \\
\hline & flian_MT & 3.22 & 1.48 & 4.89 & 0.33 & 5.00 & 0.00 & 0.00 & 4.12 & 0.98 & 0.24 & 0.84 & -0.79 & 0.07 & -0.43 & 0.13 & 0.95 & 0 & 0 \\
\hline \multirow{2}{*}{$\begin{array}{l}\text { Anthocianin } \\
\text { Tonality }\end{array}$} & toan_BT & 1.00 & 0.00 & 5.00 & 0.00 & 3.00 & 0.00 & 0.00 & 3.02 & 1.86 & 0.62 & 0.72 & -0.02 & 0.11 & -1.85 & 0.23 & 0.94 & 0 & 0 \\
\hline & toan_ML & 1.00 & 0.00 & 5.00 & 0.00 & 3.00 & 0.00 & 0.00 & 3.21 & 1.86 & 0.58 & 0.71 & -0.21 & 0.11 & -1.80 & 0.22 & 0.89 & 0 & 0 \\
\hline \multirow{3}{*}{ Corolla Colour } & corcol_BT & 1.00 & 0.00 & 5.00 & 0.00 & 4.11 & 0.33 & 0.08 & 3.00 & 1.78 & 0.59 & 0.76 & -0.01 & 0.07 & -1.78 & 0.13 & 0.97 & 0 & 0 \\
\hline & corcol_ML & 1.00 & 0.00 & 5.00 & 0.00 & 3.33 & 1.32 & 0.40 & 3.23 & 1.78 & 0.55 & 0.76 & -0.20 & 0.07 & -1.75 & 0.13 & 0.97 & 0 & 0 \\
\hline & corcol_MT & 4.33 & 1.00 & 5.00 & 0.00 & 4.67 & 0.50 & 0.11 & 4.49 & 1.10 & 0.24 & 0.51 & -2.08 & 0.07 & 3.26 & 0.13 & 0.87 & 0 & 0 \\
\hline $\begin{array}{l}\text { Hypocotyl } \\
\text { Anthocyanin }\end{array}$ & hyan & 0.67 & 0.29 & 4.83 & 1.26 & 3.00 & 0.50 & 0.17 & 2.88 & 1.34 & 0.47 & 0.94 & -0.18 & 0.12 & -0.98 & 0.23 & 0.98 & 1 & 0 \\
\hline $\begin{array}{c}\text { Speed of } \\
\text { emergence index }\end{array}$ & sei & 11.67 & 1.53 & 5.67 & 1.53 & 5.67 & 1.15 & 0.20 & 13.65 & 3.00 & 0.22 & 0.90 & 1.27 & 0.12 & 4.80 & 0.23 & 0.98 & 44 & 0 \\
\hline
\end{tabular}




\subsection{Statistical Analyses and QTL Detection}

Statistical analyses were performed using $R$ software [55]. A conventional analysis of variance was applied to estimate genotype and environment effects based on the linear model $Y_{i j}=\mu+g_{i}+b_{j}+e_{i j}$, where $\mu, g, b$ and e represent, respectively, the overall mean, the genotypic effect, the block effect and the error. Broad-sense heritability values were given by $\sigma^{2} G /\left(\left[\sigma^{2}{ }_{G}+\sigma^{2} E\right] / n\right)$, where " $\sigma 2 G$ " represents the genetic variance, " $\sigma 2 E^{\prime}$ the residual variance and " $n$ " the number of blocks. Correlations between traits were estimated using the Spearman coefficient, and normality, kurtosis and skewness were assessed with the Shapiro-Wilks test $(\alpha=0.05)$. Segregation was considered as transgressive when at least one individual RIL recorded a trait value higher or lower by at least two standard deviations than the higher or lower scoring parental line. QTL detection was performed considering each location independently and was based on the newly developed map using MQM [56,57] mapping, as implemented in MapQTL $\mathrm{v} 4$ software [58]. QTLs were initially identified using interval mapping, after which one linked marker per putative QTL was treated as a co-factor in the approximate multiple QTL model. Co-factor selection and MQM analysis were repeated until no new QTL could be identified. LOD thresholds for declaring a QTL to be significant at the $5 \%$ genome-wide probability level were established empirically by applying 1000 permutations per trait [59]. Additive and dominance genetic effects, as well as the percentage of the phenotypic variation (PVE) explained by each QTL, were obtained from the final multiple QTL model. Individual QTLs were prefixed by a trait abbreviation, followed by the relevant chromosome designation-BT, ML or MT—which was added as a suffix when a QTL was expressed in a site-specific manner. Confidence interval of the QTL was calculated at a LODmax-1 interval or at least by considering $0.5 \mathrm{Mb}$ upstream and downstream (if not explicitly reported in the text) the marker identified at the QTL. CMplot was used for drawing QTL results [60]. No site-specific suffix was added to the hyan and sei QTLs, as these two traits were assessed in a single environment.

\section{Results}

\subsection{Sequencing and Linkage Map Construction}

A total of 855 million paired-ends (PE) reads were produced, corresponding to about $257 \mathrm{~Gb}$ of data. After demultiplexing, cleaning and trimming, a total of $745 \mathrm{M}$ Illumina PE reads were retained, corresponding to an average number of PE reads per sample of $4.48 \mathrm{M}$, with a standard deviation of $2.87 \mathrm{M}$ (Figure S1). The sequence data were deposited into NCBI Short Read Archive under the Bioproject PRJNA635547.

Reads were then aligned to the reference eggplant genome [36]; close to $100 \%$ of reads were successfully mapped to single regions (no multiple mapping was permitted). A total of 10,316 polymorphic sites (i.e., markers) were identified after SNP calling using conservative filtering parameters, and were used for mapping purposes by applying a combination of R/qtl and Joinmap. At first, all markers were fed to R/qtl for linkage group identification and eventually ordered with Joinmap. Overall, 7249 markers were successfully retained and assigned to the 12 linkage groups (LG) corresponding to the haploid chromosome number of the species (Figure 2 and Figure S2). A total of 1744 markers showed segregation distortion with $p<0.001$, covering about $24 \%$ of the total mapped markers. Chromosome E02 showed the largest segregation distortion for 1423 markers, followed by E05, with 72 markers (Table 2). 


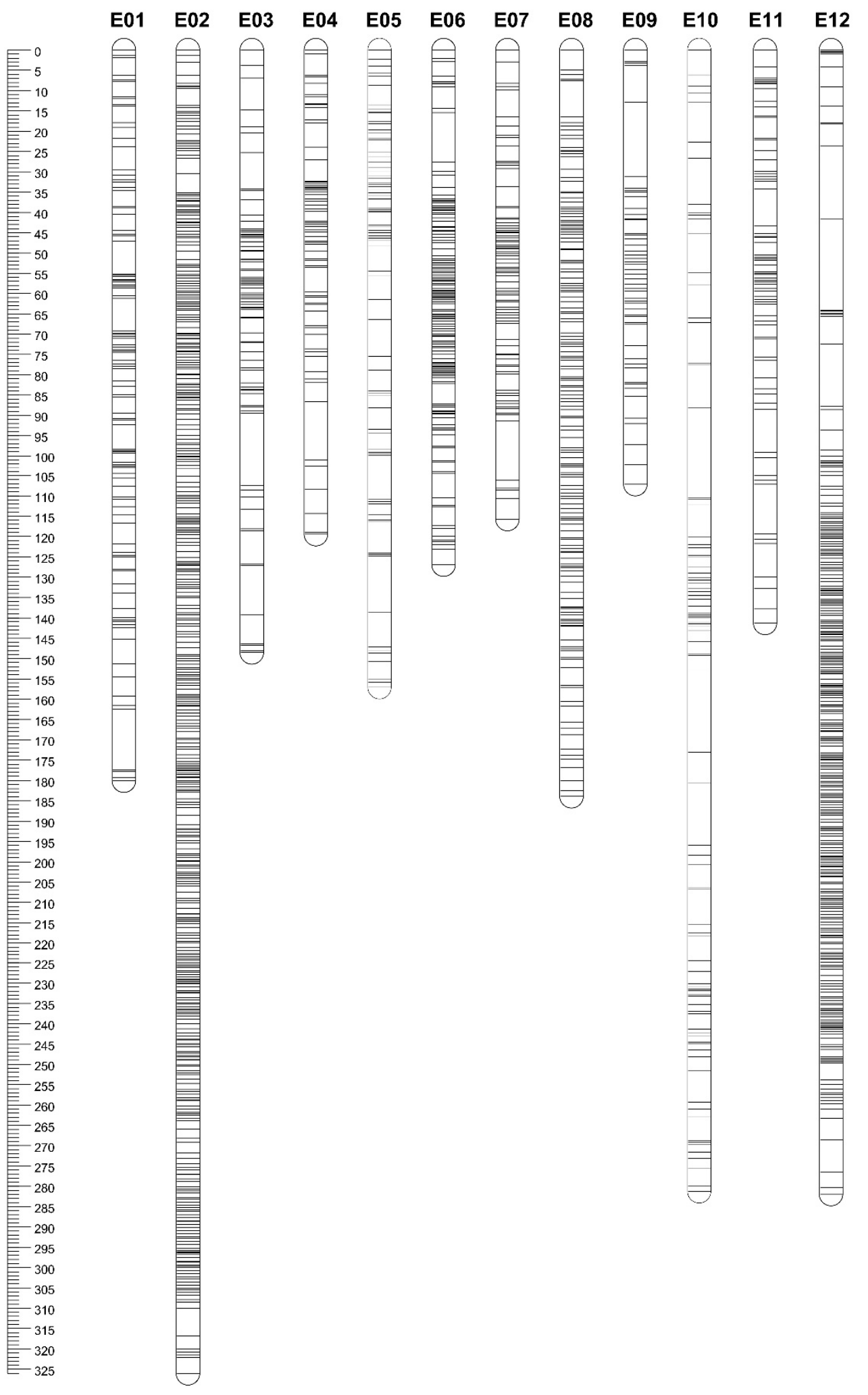

Figure 2. Eggplant linkage map depicting the size of the chromosomes and markers distribution. Marker names and map distances (in cM) are detailed in Figure S2.

The marker names, chromosome, and genetic position of all markers on the map and RILs haplotypes are included in Table S1. The linkage map spans $2169.23 \mathrm{cM}$ (Table 2), with E02 being the longest (326 cM) chromosome and containing the highest number of markers (i.e., 1454), while E09 
was the shortest $(107 \mathrm{cM})$ and contained 230 markers. Some markers belonging to contigs previously assigned to $\mathrm{CH} 0$ [36] were mapped to the 12 LGs, of which the majority were mapped on E06, while just 47 were mapped to other chromosomes. The genome-wide mean inter-locus separation was reduced (mean of $0.4 \mathrm{cM})$, with the highest value $(0.7 \mathrm{cM})$ for E05 and E10. The mapping of the SNP markers on the eggplant genome sequence revealed a total coverage of $95.88 \%(1095.72 \mathrm{Mb})$ of the diploid genome $(1142.80 \mathrm{Mb})$. The genome-wide mean inter-locus separation was $216.5 \mathrm{~kb}$, with the highest value $(411.2 \mathrm{~kb})$ in E04. The largest gap was observed on E12 $(22.45 \mathrm{cM})$, while almost all gaps were less than $5 \mathrm{cM}$. The recombination rate of different chromosomes was estimated as the quotient between the genetic distance $(\mathrm{cM})$ covered by the corresponding $\mathrm{LG}$ and the size in $\mathrm{Mb}$ of the chromosome fragment covered with markers. This value ranged from $0.81 \mathrm{cM} / \mathrm{Mb}$ on E07 to $3.91 \mathrm{cM} / \mathrm{Mb}$ on E02.

To evaluate the quality of the map obtained, we used heat maps of recombinant frequency, which highlighted that the mapped markers were ordered correctly, as the pair-wise recombination rates were noticeably low between adjacent markers (diagonal distribution of the yellow color indicates the lowest recombination rate) in the heat map for each chromosome, except E02, E06, E08 and E12 (Figure S3). Similar results were obtained when collinearity between the genetic distances of mapped SNP on each linkage group and their corresponding physical position on the eggplant chromosomes was spotted (Figure S4).

\subsection{Phenotypic Variation and Inter-Trait Correlations}

A summary of the phenotypic performance for each trait in the parental lines, hybrid $F_{1}$ and RILs, together with the skewness, kurtosis, broad sense heritability $\left(h_{2 B S}\right)$ values and presence of transgressive genotypes for each trait, are listed in Table 2. As expected, the parental lines contrasted for each trait. The female line '305E40' had a delayed emergence from the soil compared to '67/3', as evidenced by its higher sei (6 days). The '305E40' line showed lower anthocyanin content in leaves, leaf venations, flower calyxes and stems; its hypocotyl was characterized by a reddish tonality and produced flowers with a pink corolla. Conversely, line '67/3' produced violet flowers. The $\mathrm{F}_{1}$ hybrid's phenotype was intermediate between the two parents for adlan, toan and hyan. For the remaining traits, the $F_{1}$ hybrid was more similar to ' $67 / 3$ ' in all environments. Transgressive genotypes among the RILs were limited and only toward '305E40'-more precisely, three RILs for steanBT, two RILs for lveanML and adlanBT) and one RIL for lveanBT, and hyan. An exception was the speed of plant emergence, which was delayed in 44 RILs with respect to the late female parent '305E40'. The $h^{2}$ was overall high, ranging from 0.86 (lveanBT) to 0.98 (sei and hyan) (Table 2).

Significant inter-trait correlations were detected within and across locations (Table 3), and the same traits appeared to be highly correlated in the three locations. No significant correlation was detected for sei with other traits as well as between adlanMT and traits such as corcolBT, corcolML or hyan. The least correlated traits were adlan with hyan, toan and corcol (in all environments), while the most highly correlated were corcol and toan in both the BT (+0.92), and ML (+0.91) environments. 
Table 2. Parameters associated with the framework eggplant genetic map. ${ }^{a, b}$ The overall physical start and end positions of all markers of each linkage group. c The distance between the linkage group (LG) physical start and LG physical end indicates the overall physical span of all the markers of each linkage group in a particular chromosome.

\begin{tabular}{|c|c|c|c|c|c|c|c|c|c|c|c|c|c|c|}
\hline \multirow[b]{2}{*}{ LG/Chromosome } & \multirow[b]{2}{*}{$\begin{array}{l}\text { Size } \\
\text { (cM) }\end{array}$} & \multirow[b]{2}{*}{$\begin{array}{l}\text { Size } \\
(\mathrm{Mp})\end{array}$} & \multirow[b]{2}{*}{ Markers } & \multirow[b]{2}{*}{$\begin{array}{c}\text { LG } \\
\text { Physical } \\
\text { Start }(\mathbf{b p})^{\mathrm{a}}\end{array}$} & \multirow[b]{2}{*}{$\begin{array}{c}\text { LG } \\
\text { Physical } \\
\text { End (bp) }\end{array}$} & \multirow[b]{2}{*}{$\begin{array}{l}\text { Physical } \\
\text { Span } \\
(\mathbf{M b})^{\mathrm{c}} \\
\end{array}$} & \multirow[b]{2}{*}{$\begin{array}{l}\text { Max } \\
\text { Gap } \\
\text { (cM) }\end{array}$} & \multirow[b]{2}{*}{$\begin{array}{c}\text { Gap }<5 \\
\text { cM }\end{array}$} & \multirow[b]{2}{*}{ 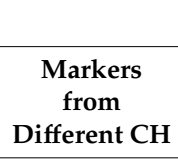 } & \multirow[b]{2}{*}{$\begin{array}{c}\text { Markers } \\
\text { from } \\
\text { CHO }\end{array}$} & \multirow[b]{2}{*}{$\begin{array}{l}\text { Distorted } \\
\text { Markers }\end{array}$} & \multicolumn{2}{|c|}{ Marker Density } & \multirow{2}{*}{$\begin{array}{c}\text { Ratio cM/Mb } \\
\text { (Estimated } \\
\text { Recombination } \\
\text { Rate) }\end{array}$} \\
\hline & & & & & & & & & & & & $\mathbf{c M}$ & $\mathbf{k b}$ & \\
\hline E01 & 180.09 & 136.53 & 426 & $1,761,388$ & $136,521,595$ & 134.76 & 14.89 & 0.984 & 0 & 0 & 54 & 0.4 & 321.3 & 1.32 \\
\hline E02 & 326.00 & 83.34 & 1454 & 5796 & $77,157,371$ & 77.15 & 6.71 & 0.999 & 9 & 3 & 1425 & 0.2 & 57.4 & 3.91 \\
\hline E03 & 148.51 & 97.01 & 408 & 36,214 & $82,766,928$ & 82.73 & 18.00 & 0.985 & 9 & 19 & 7 & 0.4 & 238.4 & 1.53 \\
\hline E04 & 119.40 & 105.67 & 258 & $1,557,104$ & $105,339,521$ & 103.78 & 14.46 & 0.973 & 0 & 0 & 0 & 0.5 & 411.2 & 1.13 \\
\hline E05 & 157.15 & 43.85 & 211 & $2,017,627$ & $43,756,820$ & 41.74 & 13.75 & 0.957 & 0 & 13 & 72 & 0.7 & 208.8 & 3.58 \\
\hline E06 & 126.94 & 108.97 & 838 & 2187 & $99,842,165$ & 99.84 & 12.19 & 0.995 & 24 & 104 & 8 & 0.2 & 130.2 & 1.16 \\
\hline E07 & 115.69 & 142.38 & 535 & 16,820 & $140,599,277$ & 140.58 & 14.79 & 0.994 & 1 & 16 & 36 & 0.2 & 266.6 & 0.81 \\
\hline E08 & 183.94 & 109.58 & 730 & 2123 & $10,680,425$ & 106.80 & 8.89 & 0.999 & 0 & 2 & 1 & 0.3 & 150.3 & 1.68 \\
\hline E09 & 107.06 & 36.10 & 230 & 11,386 & $34,244,824$ & 34.23 & 18.18 & 0.978 & 1 & 15 & 1 & 0.5 & 157.6 & 2.97 \\
\hline E10 & 281.23 & 106.64 & 386 & 701,005 & $106,482,885$ & 105.78 & 22.29 & 0.956 & 0 & 0 & 68 & 0.7 & 277.0 & 2.64 \\
\hline E11 & 141.34 & 72.29 & 231 & 213,621 & $72,208,518$ & 71.99 & 12.24 & 0.974 & 3 & 59 & 39 & 0.6 & 314.3 & 1.96 \\
\hline E12 & 281.90 & 100.42 & 1542 & 10,639 & $96,335,130$ & 96.32 & 22.45 & 0.995 & 0 & 1 & 33 & 0.2 & 65.2 & 2.81 \\
\hline Total & 2169.23 & 1142.80 & 7249.00 & & & 1095.72 & & & 47 & 232 & 1744 & 0.4 & 216.5 & 2.12 \\
\hline
\end{tabular}


Table 3. Inter-trait Spearman correlations assessed in the mapping population. In green, significant correlation at $p<0.05$, in blue at $p<0.01$.

\begin{tabular}{|c|c|c|c|c|c|c|c|c|c|c|c|c|c|c|c|c|c|c|}
\hline & adlanML & adlanMT & corcolBT & corcolML & corcolMT & flianBT & flianML & flianMT & sei & hyan & lveanBT & lveanML & lveanMT & steanBT & steanML & steanMT & toanBT & toanML \\
\hline adlanBT & 0.90 & 0.81 & 0.21 & 0.21 & 0.21 & 0.43 & 0.45 & 0.50 & 0.02 & 0.19 & 0.49 & 0.42 & 0.66 & 0.38 & 0.38 & 0.39 & 0.20 & 0.16 \\
\hline adlanML & & 0.83 & 0.20 & 0.19 & 0.18 & 0.37 & 0.43 & 0.45 & 0.00 & 0.17 & 0.40 & 0.41 & 0.66 & 0.32 & 0.37 & 0.38 & 0.19 & 0.18 \\
\hline adlanMT & & & 0.15 & 0.15 & 0.18 & 0.39 & 0.42 & 0.45 & 0.00 & 0.11 & 0.42 & 0.39 & 0.65 & 0.30 & 0.37 & 0.36 & 0.12 & 0.15 \\
\hline corcolBT & & & & 0.85 & 0.60 & 0.57 & 0.53 & 0.53 & 0.03 & 0.69 & 0.57 & 0.61 & 0.42 & 0.74 & 0.65 & 0.69 & 0.92 & 0.83 \\
\hline corcolML & & & & & 0.68 & 0.51 & 0.54 & 0.54 & 0.05 & 0.68 & 0.58 & 0.58 & 0.44 & 0.75 & 0.68 & 0.71 & 0.81 & 0.91 \\
\hline corcolMT & & & & & & 0.42 & 0.37 & 0.41 & -0.12 & 0.48 & 0.45 & 0.44 & 0.34 & 0.60 & 0.56 & 0.55 & 0.58 & 0.63 \\
\hline flianBT & & & & & & & 0.85 & 0.81 & 0.04 & 0.42 & 0.80 & 0.79 & 0.55 & 0.79 & 0.77 & 0.73 & 0.50 & 0.45 \\
\hline flianML & & & & & & & & 0.85 & 0.02 & 0.37 & 0.83 & 0.81 & 0.60 & 0.75 & 0.83 & 0.78 & 0.42 & 0.47 \\
\hline flianMT & & & & & & & & & 0.02 & 0.44 & 0.82 & 0.78 & 0.61 & 0.77 & 0.80 & 0.80 & 0.45 & 0.46 \\
\hline sei & & & & & & & & & & 0.09 & 0.07 & -0.01 & -0.02 & 0.05 & -0.01 & 0.00 & 0.07 & -0.01 \\
\hline hyan & & & & & & & & & & & 0.52 & 0.43 & 0.27 & 0.65 & 0.53 & 0.54 & 0.66 & 0.65 \\
\hline lveanBT & & & & & & & & & & & & 0.83 & 0.59 & 0.83 & 0.82 & 0.80 & 0.52 & 0.50 \\
\hline lveanML & & & & & & & & & & & & & 0.52 & 0.78 & 0.83 & 0.83 & 0.55 & 0.57 \\
\hline lveanMT & & & & & & & & & & & & & & 0.54 & 0.59 & 0.62 & 0.35 & 0.36 \\
\hline steanBT & & & & & & & & & & & & & & & 0.88 & 0.88 & 0.70 & 0.68 \\
\hline steanML & & & & & & & & & & & & & & & & 0.91 & 0.59 & 0.62 \\
\hline steanMT & & & & & & & & & & & & & & & & & 0.62 & 0.65 \\
\hline $\operatorname{toanBT}$ & & & & & & & & & & & & & & & & & & 0.84 \\
\hline
\end{tabular}




\subsection{QTL Analysis}

LOD score, percentage of variance explained (PVE), and confidence interval (CI) related to QTLs, are described in Table 4. QTL analyses on all traits and environments yielded a total of 23 major (PVE values $>10 \%$ ) and 11 minor QTLs (Figure 3).

QTL analyses for both hyan and sei, which were evaluated in a single location, highlighted one major and two minor QTLs. Separate analyses performed on each location for adlan, lvean, stean, corcol and toan resulted in the identification of a ratio between major and minor QTLs of 8/2,7/4 and 6/1 in BT, ML and MT, respectively. The majority of QTLs identified can be considered stable, as they had the same genomic position across the three locations, with the exception of the minor QTLs stean2.1, confirmed both in MT and ML, but not in BT, and corcol10.1, demonstrating a major QTL in BT and a minor QTL in ML, and not detected in MT. Moreover, the major QTL corcol5.1, detected both in BT and ML, was mapped in a different position of E05 and was found as playing a minor effect in MT. For the anthocyanin-related QTLs, the positive alleles responsible for an increase in the anthocyanin content and for the presence of a violet vs. reddish pigmentation derived from ' $67 / 3$ '. Concerning the speed of emergence index, for all the QTLs but sei2.2, the allele increasing seed vigor derived from ' $67 / 3$ '. The largest single QTL effect was associated with flian10.1_MT (69.3\% of the PVE). The additive effects of all the QTLs were significant at $p<0.05$.

All the identified QTLs were distributed over five chromosomes (Table 4), namely E02, E04, E05, E07, E10, and two evident clusters of QTLs were detected (Figure 3). One is located on E05, which also harbors two adjacent sub-clusters of QTLs conserved in the three locations. The former is comprised between 62.45 to $66.5 \mathrm{cM}$, and contained QTLs for stean and toan; the other is at $75.48 \mathrm{cM}$, and included coincident QTLs for hyan, toan and corcol. The second main cluster is on E10 at 231.77-236.98 cM and included the major QTLs stean10.1, lvean10.1, adlan10.1 and flian10.1, and the minor QTLs hyan10.1, corcol10.1, and toan10.1.

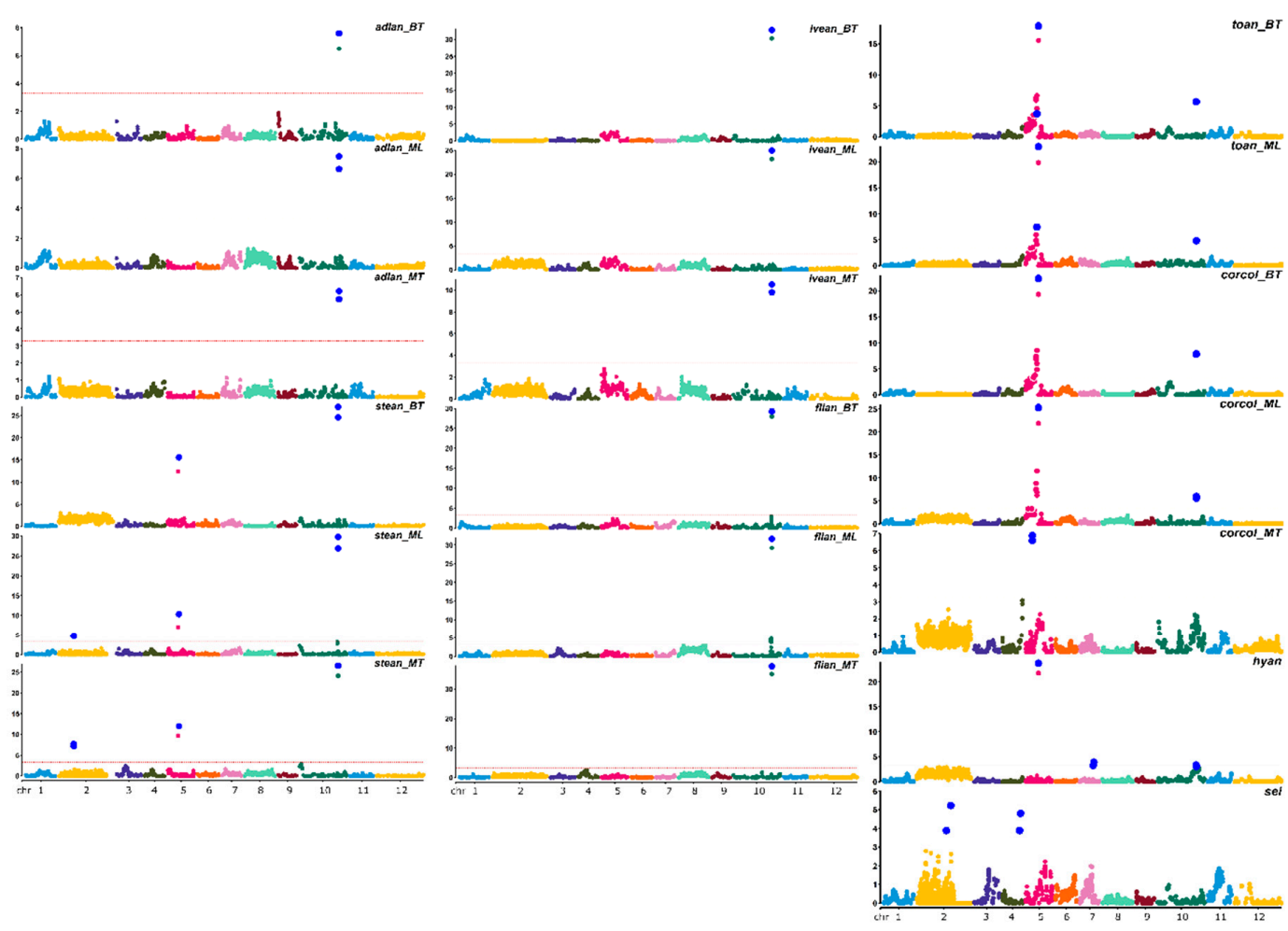

Figure 3. QTLs identified for the traits in study. Blue dots represent markers within the confidence interval of the QTL (LODmax-1 interval), with LOD values plotted against genome locations. Red lines in the Manhattan plots indicate LOD significance threshold. 
Table 4. QTL detected in the mapping population. For each trait the chromosomal location (Chr.), the genome-wide thresholds (GW) at $p=0.05$ (as determined from 1000 permutations) are indicated.

\begin{tabular}{|c|c|c|c|c|c|c|c|c|c|c|c|c|c|c|c|c|c|c|c|c|c|c|c|c|c|c|c|}
\hline \multirow{3}{*}{ Trait } & \multicolumn{9}{|c|}{ Battipaglia } & \multicolumn{9}{|c|}{ Montanaso Lombardo } & \multicolumn{9}{|c|}{ Monsampolo del Tronto } \\
\hline & GW & QTL & \multicolumn{3}{|c|}{ Position } & \multirow[t]{2}{*}{ LOD } & \multirow[t]{2}{*}{ CI } & \multirow[t]{2}{*}{ PVE } & \multirow[t]{2}{*}{ A } & \multirow[t]{2}{*}{ GW } & \multirow[t]{2}{*}{ QTL } & \multicolumn{3}{|c|}{ Position } & \multirow[t]{2}{*}{ LOD } & \multirow[t]{2}{*}{$\mathrm{CI}$} & \multirow[t]{2}{*}{ PVE } & \multirow[t]{2}{*}{$\mathbf{A}$} & \multirow[t]{2}{*}{ GW } & \multirow[t]{2}{*}{ QTL } & \multicolumn{3}{|c|}{$\begin{array}{l}\text { Position } \\
\end{array}$} & \multirow[t]{2}{*}{ LOD } & \multirow[t]{2}{*}{$\mathrm{CI}$} & \multirow[t]{2}{*}{ PVE } & \multirow[t]{2}{*}{$\mathbf{A}$} \\
\hline & & & Chr. & $\mathrm{cM}$ & Locus & & & & & & & Chr. & $\mathrm{cM}$ & Locus & & & & & & & Chr. & $\mathrm{cM}$ & Locus & & & & \\
\hline adlan & 3.3 & $\begin{array}{l}\text { adlan } \\
10.1 \_B T\end{array}$ & E10 & 236.98 & $\begin{array}{c}\text { CH10_95 } \\
003635\end{array}$ & 7.59 & 236.98 & 21.0 & -0.6002 & 3.3 & $\begin{array}{c}\text { adlan } \\
\text { 10.1_ML }\end{array}$ & E10 & 236.98 & $\begin{array}{c}\text { CH10_95 } \\
003635\end{array}$ & 7.47 & 236.98 & 20.4 & -0.5872 & 3.3 & $\begin{array}{c}\text { adlan } \\
\text { 10.1_MT }\end{array}$ & E10 & 236.98 & $\begin{array}{c}\text { CH10_95 } \\
003635\end{array}$ & 6.21 & 236.987 & 17.7 & -0.3465 \\
\hline \multirow[t]{3}{*}{ stean } & 3.2 & & & & & & & & & \multirow[t]{3}{*}{3.2} & $\begin{array}{c}\text { stean } \\
2.1 \_M L\end{array}$ & E02 & 88.73 & $\begin{array}{l}\text { CH02_30 } \\
555633\end{array}$ & 4.90 & 88.73 & 5.6 & -0.2294 & 3.2 & $\begin{array}{c}\text { stean2.1 } \\
\text { _ML }\end{array}$ & E02 & 88.73 & $\begin{array}{l}\text { CH02_30 } \\
555713\end{array}$ & 7.71 & 88.733 & 9.5 & -0.3255 \\
\hline & & $\begin{array}{l}\text { stean } \\
5.1 \_\mathrm{BT}\end{array}$ & E05 & 66.39 & $\begin{array}{l}\text { CH05_36 } \\
124744\end{array}$ & 15.58 & $\begin{array}{l}62.45- \\
66.51\end{array}$ & 21.5 & -0.4263 & & $\begin{array}{c}\text { stean } \\
5.1 \_\mathrm{ML}\end{array}$ & E05 & 66.39 & $\begin{array}{c}\text { CH05_36 } \\
124744\end{array}$ & 9.22 & 66.39 & 13.0 & -0.3156 & & $\begin{array}{c}\text { stean } \\
5.1 \_\mathrm{ML}\end{array}$ & E05 & 64.51 & $\begin{array}{l}\text { CH05_36 } \\
124744\end{array}$ & 9.70 & $\begin{array}{l}62.45- \\
64.516\end{array}$ & 16.8 & -0.3882 \\
\hline & & $\begin{array}{c}\text { stean } \\
10.1 \_B T\end{array}$ & E10 & 231.46 & $\begin{array}{c}\text { CH10_94 } \\
779014\end{array}$ & 26.93 & 231.46 & 45.1 & -0.6000 & & $\begin{array}{c}\text { stean } \\
10.1 \_M L\end{array}$ & E10 & 231.46 & $\begin{array}{l}\text { CH10_94 } \\
779014\end{array}$ & 25.92 & 231.46 & 48.1 & -0.5894 & & $\begin{array}{c}\text { stean } \\
\text { 10.1_MT }\end{array}$ & E10 & 231.46 & $\begin{array}{c}\text { CH10_94 } \\
779014\end{array}$ & 20.76 & 231.465 & 40.3 & -0.5851 \\
\hline lvean & 3.2 & $\begin{array}{c}\text { lvean } \\
10.1 \_B T\end{array}$ & E10 & 231.46 & $\begin{array}{c}\text { CH10_94 } \\
779014\end{array}$ & 32.78 & 231.46 & 64.2 & -0.7883 & 3.2 & $\begin{array}{c}\text { lvean } \\
\text { 10.1_ML }\end{array}$ & E10 & 231.46 & $\begin{array}{l}\text { CH10_94 } \\
779014\end{array}$ & 24.92 & 231.46 & 53.2 & -0.6202 & 3.2 & $\begin{array}{c}\text { lvean } \\
\text { 10.1_MT }\end{array}$ & E10 & 231.46 & $\begin{array}{c}\text { CH10_94 } \\
779014\end{array}$ & 10.52 & 231.465 & 28.2 & -0.5629 \\
\hline flian & 3.1 & $\begin{array}{c}\text { flian } \\
\text { f0.1_BT }\end{array}$ & E10 & 231.46 & $\begin{array}{c}\text { CH10_94 } \\
779014\end{array}$ & 29.26 & 231.46 & 59.5 & -0.5680 & 3.1 & $\begin{array}{c}\text { flian } \\
10.1 \_M L\end{array}$ & E10 & 231.46 & $\begin{array}{l}\text { CH10_94 } \\
779014\end{array}$ & 31.64 & 231.46 & 61.9 & -0.6544 & 3.1 & $\begin{array}{c}\text { flian } \\
\text { 10.1_MT }\end{array}$ & E10 & 231.46 & $\begin{array}{c}\text { CH10_94 } \\
779014\end{array}$ & 37.70 & 231.465 & 69.3 & -0.7393 \\
\hline toan & 3.4 & $\begin{array}{l}\text { toan } \\
\text { 5.1_BT }\end{array}$ & E05 & 75.48 & $\begin{array}{c}\text { CH05_37 } \\
533757\end{array}$ & 17.89 & 75.48 & 35.7 & -110.9 & 3.4 & $\begin{array}{c}\text { toan } \\
5.1 \text { ML }\end{array}$ & E05 & 75.48 & $\begin{array}{c}\text { CH05_37 } \\
533757\end{array}$ & 22.92 & 75.48 & 43.9 & -116208 & & & & & & & & & \\
\hline & & $\begin{array}{c}\text { toan } \\
5.2 \_ \text {BT }\end{array}$ & E05 & 66.39 & $\begin{array}{c}\text { CH05_36 } \\
076199\end{array}$ & 3.72 & $\begin{array}{l}61.55- \\
66.39\end{array}$ & 5.2 & -0.6245 & & $\begin{array}{c}\text { toan } \\
5.2 \_\mathrm{ML}\end{array}$ & E05 & 66.39 & $\begin{array}{l}\text { CH05_36 } \\
124744\end{array}$ & 7.44 & $\begin{array}{c}61.55- \\
66.39\end{array}$ & 8.7 & -0.7422 & & & & & & & & & \\
\hline & & $\begin{array}{c}\text { toan } \\
10.1 \_ \text {BT }\end{array}$ & E10 & 232.77 & $\begin{array}{l}\text { CH10_94 } \\
275882\end{array}$ & 5.67 & 232.77 & 9.3 & -0.5498 & & $\begin{array}{c}\text { toan } \\
10.1 \_\mathrm{ML}\end{array}$ & E10 & 232.77 & $\begin{array}{l}\text { CH10_94 } \\
275882\end{array}$ & 4.82 & 232.77 & 6.8 & -0.4464 & & & & & & & & & \\
\hline corcol & 3.3 & $\begin{array}{c}\text { corcol } \\
5.1 \_B T\end{array}$ & E05 & 75.48 & $\begin{array}{l}\text { CH05_37 } \\
533757\end{array}$ & 22.39 & 75.484 & 40.2 & -107.477 & 3.3 & $\begin{array}{c}\text { corcol } \\
\text { 5.1_ML }\end{array}$ & E05 & 75.48 & $\begin{array}{c}\text { CH05_-37 } \\
533757\end{array}$ & 25.31 & 75.48 & 45.2 & -112175 & 3.3 & $\begin{array}{c}\text { corcol } \\
5.1 \_M T\end{array}$ & E05 & 39.39 & $\begin{array}{l}\text { CH05_17 } \\
086140\end{array}$ & 6.88 & 39.397 & 19.3 & -0.3440 \\
\hline & & $\begin{array}{c}\text { corcol } \\
10.1 \_B T \\
\end{array}$ & E10 & 232.77 & $\begin{array}{c}\text { CH10_94 } \\
27582 \\
\end{array}$ & 7.88 & 232.77 & 11.1 & -0.5493 & & $\begin{array}{c}\text { corcol } \\
10.1 \_M L \\
\end{array}$ & E10 & 232.77 & $\begin{array}{l}\text { CH10_94 } \\
281914\end{array}$ & 5.95 & 232.77 & 7.7 & -0.4507 & & & & & & & & & \\
\hline hyan & & & & & & & & & & 3.3 & hyan5.1 & E05 & 75.48 & $\begin{array}{c}\text { CH05_37 } \\
533757\end{array}$ & 23.72 & 75.48 & 48.1 & -0.9234 & & & & & & & & & \\
\hline & & & & & & & & & & & hyan7.1 & E07 & 83.94 & $\begin{array}{l}\text { CH07_13 } \\
2761839\end{array}$ & 3.93 & $\begin{array}{c}79.32- \\
83.94\end{array}$ & 5.8 & -0.3223 & & & & & & & & & \\
\hline & & & & & & & & & & & hyan10.1 & E10 & 231.46 & $\begin{array}{c}\text { CH10_94 } \\
684020\end{array}$ & 3.37 & $\begin{array}{l}230.12- \\
233.45\end{array}$ & 4.5 & -0.2807 & & & & & & & & & \\
\hline sei & & & & & & & & & & 3.0 & sei2.1 & E02 & 204.18 & $\underset{633733}{\mathrm{CH} 02544}$ & 5.23 & 204.18 & 10.4 & -5.689 & & & & & & & & & \\
\hline & & & & & & & & & & & sei2. 2 & E02 & 176.24 & $\begin{array}{c}\text { CH02_63 } \\
996392\end{array}$ & 3.89 & 176.24 & 7.6 & 5.109 & & & & & & & & & \\
\hline & & & & & & & & & & & sei4.1 & E04 & 108.42 & $\begin{array}{l}\text { CH04_10 } \\
2121728\end{array}$ & 4.81 & $\begin{array}{l}102.22- \\
114.85\end{array}$ & 9.7 & -0.8733 & & & & & & & & & \\
\hline
\end{tabular}




\subsubsection{QTL Affecting Plant Pigmentation in Eggplant}

Adaxial Leaf Lamina Anthocyanin (adlan)

A single major QTL, adlan10.1, was mapped on E10 at 236.987 cM next to the marker CH10_95003635 in all the three environments, and explains $21 \%$ of PVE in BT, 20.4\% in ML and $17.7 \%$ in MT.

Stem Anthocyanins (stean)

Two major QTLs on E05 and E10 were detected in all the environments. The QTL stean10.1 on E10 explains from $40 \%$ to $48 \%$ of the PVE and is located at $231.46 \mathrm{cM}$ (proximal marker: CH10_94779014). The second major QTL stean5.1, explains from $13 \%$ to $21 \%$ of the PVE and maps on E05, within the same confidence interval (62.45-66.51 cM) in all locations (proximal marker: CH05_36124744). A third minor QTL was spotted in ML and MT, but not in BT, on E02 at $88.73 \mathrm{cM}$ (proximal marker: CH02_30555633), and explains $6 \%$ and $9 \%$ of PVE, respectively.

Leaf Venation Anthocyanins (lvean)

One major QTL determining anthocyanin pigmentation in leaf venation (lvean10.1), explaining from $29 \%$ to $64 \%$ of PVE, was mapped on E10 in all locations at $231.46 \mathrm{cM}$ (proximal marker: CH10_94779014).

Flower Anthocyanin Intensity (flian)

The unique major QTL flian10.1 mapped, in all environments, on E10 at $231.46 \mathrm{cM}$ (proximal marker: CH10_94779014), explains from 59\% to $69 \%$ of the PVE.

Anthocyanin Tonality (toan)

Data for toan were only available for BT and ML environments. A major QTL (toan5.1) explaining $36 \%$ and $47 \%$ in BT and ML, respectively, was spotted on E05 at 75.48 (proximal marker: CH05_37533757). A minor QTL (toan5.2) was identified on E05 within the same CI in both locations at 61.55-66.39 cM. A third QTL with a minor effect (PVE explained from 6.8\% to 9.3\%) was spotted on E10 at $231.46 \mathrm{cM}$.

Hypocotyl Anthocyanins (hyan)

The QTL analysis for this trait was performed with data from one environment. A major and two minor QTLs were spotted on E05, E07 and E10, respectively. The largest effect locus (hyan5.1) explains $48 \%$ of PVE and is located on E05 at $75.48 \mathrm{cM}$ (proximal marker: CH05_37533757). A minor QTL (hyan7.1), explaining 6\% of the PVE, maps on E07 at $83.95 \mathrm{cM}$ (proximal marker: CH07_132671839). The QTL with the lower effect (4.5\% PVE explained) was located on E10 at $231.46 \mathrm{cM}$ (proximal marker: CH10_94779014).

Corolla Colour (corcol)

A major QTL (corcol5.1), explaining from $40 \%$ to $44 \%$ of the PVE, was spotted on E05 at $75.48 \mathrm{cM}$ (proximal marker: CH05_37533757) in BT and ML, while corcol5.2 was located at $39.40 \mathrm{cM}$ (proximal marker CH05_17086140) and explains 19\% of PVE in MT. A minor QTL (corcol10.1), explaining $7.7 \%-11.1 \%$ of the PVE, was spotted on E10 in BT and ML (not in MT) in the same position at $232.77 \mathrm{cM}$ (proximal marker: CH10_94275882).

\subsubsection{QTL Affecting Speed of Plant Emergence Index}

On E02, we mapped the largest effect locus (sei2.1), explaining 10.4\% of PVE and located at $204.18 \mathrm{cM}$ (proximal marker: CH02_63996392), together with a minor QTL (sei 2.2), at $176 \mathrm{cM}$ (proximal marker: CH02_54633733), which explains 8\% of the PVE. A further minor QTL was located on E04, at $108.43 \mathrm{cM}$ (proximal marker: CH04_102121728), which explains $10 \%$ of PVE. 


\subsection{Candidate Genes Identification}

To find out candidate genes at the identified QTLs in the confidence interval region, we exploited the annotation of the available eggplant genome sequence by searching for genes, including transcription factors, putatively involved in the genetic control of the traits in study. For each QTL, the position, best candidate genes ID, acronym (abbreviation) and predicted function are reported in Table 5.

Table 5. Candidate genes spotted within the interval of detected QTLs. For each QTL, position, best candidate genes ID, acronym (abbreviation) and putative function are provided.

\begin{tabular}{|c|c|c|c|c|}
\hline \multirow{2}{*}{ QTL } & \multirow{2}{*}{$\begin{array}{l}\text { Approximative } \\
\text { Position }\end{array}$} & \multicolumn{2}{|c|}{ Gene } & \multirow[t]{2}{*}{ Predicted Function } \\
\hline & & IDs SMEL_ & Abbreviation & \\
\hline \multirow{3}{*}{ sei 2.1} & $9.2 \mathrm{Mb}$ & $002 \mathrm{~g} 153950.960$ & NHL6 & 2x NDR1/HIN1-like protein 6 \\
\hline & \multirow{2}{*}{$54 \mathrm{Mb}$} & 002g158620 & PECS-2.1 & Pectinesterases 2 \\
\hline & & 002g158940 & SNL2 & Paired amphipathic helix protein Sin3-like 2 \\
\hline \multirow{4}{*}{$\begin{array}{c}\text { between } \\
\text { sei } 2.1 \text { and } \\
\text { sei } 2.2\end{array}$} & \multirow{4}{*}{$\sim 54-60 \mathrm{Mb}$} & 002g159100 & LAC11 & Laccase \\
\hline & & 002g159470 & ENY & Zinc finger ENHYDROUS \\
\hline & & 002g159370.380 & PLT6 & $2 \mathrm{x}$ polyol transporter \\
\hline & & 002g159480 & GBF1 & G-box-binding factor 1 \\
\hline \multirow{4}{*}{ sei 2.2} & \multirow{4}{*}{$60-63 \mathrm{Mb}$} & $002 \mathrm{~g} 160070.080$ & CAR2 & 2x C2-Domain Abscisic Acid-Related Proteins \\
\hline & & 002g160170 & GRDP1 & Glycine-rich domain-containing protein 1 \\
\hline & & 002g159720 & TCP1 & T-complex protein 1 subunit zeta 1 \\
\hline & & 002g159870 & MSR4 & Peptide methionine sulfoxide reductase \\
\hline \multirow{7}{*}{ sei 4.1} & \multirow{5}{*}{$102 \mathrm{Mb}$} & 004g219910.920 & & 2x Serpins-ZX \\
\hline & & 004g220200-220 & NPF4.5/NPF4.3 & 3x NRT1/ PTR protein fam $4.5 / 4.3$ \\
\hline & & 004g220270 & $\mathrm{KO}$ & Ent-kaurene oxidase \\
\hline & & 004g220280 & REM16 & B3 domain transcription factor \\
\hline & & 004g220780 & GAF1 & Zinc finger GAI-ASSOCIATED FACTOR 1 \\
\hline & \multirow{2}{*}{$\sim 102 \mathrm{Mb}$} & 004g221390 & & abscisic acid $8^{\prime}$ hydrolase 4 \\
\hline & & 004g221470 & BZIP44 & bZIP transcription factor 44 \\
\hline \multirow{4}{*}{$\begin{array}{c}\text { toan10.1 } \\
\text { corcol } 10.1\end{array}$} & \multirow{2}{*}{$\sim 94 \mathrm{Mb}$} & $010 \mathrm{~g} 352310-490$ & ANS & 4x 2-oxoglutarate/Fe(II)-dependent dioxygenase \\
\hline & & 010g352500 & JRG21 & 2-oxoglutarate/Fe(II)-dependent dioxygenase \\
\hline & \multirow{2}{*}{$94 \mathrm{Mb}$} & 010g352790 & & Myb family transcription factor \\
\hline & & 010g352650 & SAC8 & Phosphoinositide phosphatase \\
\hline \multirow{5}{*}{$\begin{array}{l}\text { lvean } 10.1 \\
\text { stean } 10.1 \\
\text { flian10.1 } \\
\text { hyan } 10.1\end{array}$} & \multirow{4}{*}{$94.7 \mathrm{Mb}$} & 010g352910 & BES1/BZR1 & BES1/BZR1 transcription factor \\
\hline & & $010 \mathrm{~g} 352980$ & & Ankyrin repeat-containing protein \\
\hline & & $010 \mathrm{~g} 352930$ & DREB2C & $\begin{array}{l}\text { Dehydration-Responsive Element-Binding } \\
\text { Protein 2C }\end{array}$ \\
\hline & & 010g353040 & PPC6-1 & protein phosphatase $2 \mathrm{C}$ \\
\hline & $\sim 94.7 \mathrm{Mb}$ & 010g353090-110 & RAPTOR & $\begin{array}{c}\text { 3x RAPTOR - Regulatory-associated protein } \\
\text { of TOR }\end{array}$ \\
\hline \multirow{2}{*}{ adlan 10.1} & \multirow{2}{*}{$95 \mathrm{Mb}$} & 010g353170-200 & & $5 x$ peroxidase \\
\hline & & 010g353200 & & Protein disulfide-isomerase \\
\hline \multirow{4}{*}{ hyan 7.1} & \multirow{4}{*}{$132.7 \mathrm{Mb}$} & 007g289310-410 & MYBs & 6x similar to MYB15/14/58/102 \\
\hline & & 007g289700.710 & NDB & 2x NAD $(\mathrm{P}) \mathrm{H}$ dehydrogenase \\
\hline & & 007g289780 & & F-box/kelch-repeat protein \\
\hline & & $007 \mathrm{~g} 289410$ & PPC6-6 & protein phosphatase $2 \mathrm{C}$ \\
\hline
\end{tabular}


Table 5. Cont.

\begin{tabular}{|c|c|c|c|c|}
\hline \multirow{2}{*}{ QTL } & \multirow{2}{*}{$\begin{array}{l}\text { Approximative } \\
\text { Position }\end{array}$} & \multicolumn{2}{|c|}{ Gene } & \multirow[t]{2}{*}{ Predicted Function } \\
\hline & & IDs SMEL_ & Abbreviation & \\
\hline \multirow{4}{*}{ stean 2.1} & \multirow{4}{*}{$30.5 \mathrm{Mb}$} & 002g155860 & & Ankyrin repeat-containing protein \\
\hline & & 002g155880 & LIMYB & L10-interacting MYB domain-containing protein \\
\hline & & 002g155890 & HSP70 & Similar to Heat shock $70 \mathrm{kDa}$ protein \\
\hline & & 002g155950.970 & LARP1C & 2x La-related protein 1C-like \\
\hline \multirow{3}{*}{$\begin{array}{c}\text { stean } 5.1 \\
\text { toan } 5.2\end{array}$} & \multirow{2}{*}{$36.2 \mathrm{Mb}$} & 005g235930 & HSP & 17.3 kDa class II heat shock protein \\
\hline & & 005g236210 & BHLH93 & similar to Transcription factor bHLH93 \\
\hline & $\sim 36.2 \mathrm{Mb}$ & 005g236240 & AAT & Acetyl-CoA-benzylalcohol acetyltransferase \\
\hline \multirow{6}{*}{$\begin{array}{c}\text { hyan } 5.1 \\
\text { toan } 5.1 \\
\text { corcol } 5.1\end{array}$} & $\sim 37.5 \mathrm{Mb}$ & 005g236840-90 & & 7x Calmodulin-like genes \\
\hline & $37.5 \mathrm{Mb}$ & $005 g 236910.20$ & BKI1 & 2x BR1 kinase inhibitors \\
\hline & \multirow{4}{*}{$\sim 37.5 \mathrm{Mb}$} & $005 g 236720.30$ & TOGT1 & 2x Scopoletin glucosyltransferase \\
\hline & & 005g236480 & BHLH84 & Transcription factor bHLH84 \\
\hline & & $005 g 236490.00$ & AZF3,ZAT10 & $2 \times$ Zinc finger protein \\
\hline & & $005 g 236570-620$ & CYP81Q32,VQ31 & cytochrome p450 \\
\hline
\end{tabular}

sei2.1

The major QTL associated to sei lies on E02 at 204.18 cM and includes four markers in the confidence interval, whose physical positions are quite distant, i.e., 48-54 Mb and 9.2 Mb. The top-linked marker is located at around $54 \mathrm{Mb}$, in a region containing 15 genes, among which a Pectinesterase 2 and SNL2, a protein involved in response to hormonal stimulus, appeared to be good candidates. The region at $9.2 \mathrm{Mb}$ contains two colocalizing markers: in the interval around $0.3 \mathrm{Mb}$, five genes are present, including two putative NHL6, putatively involved in the response to abscisic acid (ABA).

sei2.2

The minor QTL sei2.2 lies on E02 at $176 \mathrm{cM}$, in a region of six co-localizing markers located at 60-63 Mb. This region contains 70 genes, some of which may be eligible as candidates, such as the ones associated to the response to abscisic acid (GRDP1 and CAR2), two polyol transporters, a TCP1 and peptide methionine sulfoxide reductase. In the region beneath sei2.1 and sei2.2, a laccase, a zinc finger and a G-box-binding factor 1 putatively involved in seed germination are also present.

sei4.1

In the interval around $0.5 \mathrm{Mb}$ from sei4.1, several Serpins-ZX and NRT1/PTR genes protein were identified, as well as an Ent-kaurene oxidase and a B3 domain protein, both involved in gibberellin synthesis. By slightly relaxing the confidence interval (until around $1 \mathrm{M}$ ), other genes involved in the signaling pathway of ABA degradation (among which an abscisic acid hydroxylase) were found.

stean10.1, lvean10.1, flian10.1, hyan10.1

The major QTLs stean10.1, lvean10.1, flian10.1, identified at $231.47 \mathrm{cM}$ on E10 in the three environments, as well as the minor QTL hyan10.1, lie at around $94.7 \mathrm{Mb}$, in the top part of the cluster of QTLs associated to anthocyanin amount/coloration intensity and very close to the QTLs for corcol and toan. In this region, 17 genetic markers are co-segregating, corresponding to a physical interval comprised between 94.54 and $94.88 \mathrm{Mb}$. The region includes 19 annotated genes, among which a BES1/BRZ1 transcription factor, a DREB2C (dehydration-responsive element-binding protein 2C), an Ankyrin repeat-containing protein and a PPC6-1 (putative protein phosphatase 2C) are eligible as candidates involved in the anthocyanin synthesis. By slightly relaxing the confidence interval, three proteins annotated as regulatory-associated protein of TOR (RAPTOR) are also present. 
corcol10.1-toan10.1

The QTLs corcol10.1 and L toan10.1, both identified in BT and ML in the cluster on E10 at $232.77 \mathrm{cM}$ lean in a region located on E10 containing ten co-localizing markers and physically located at 93.8-94.2 $\mathrm{Mb}$. In this region, the most promising candidate genes are a putative MYB family transcription factor (SMEL_010g352790) and a phosphoinositide phosphatase, SAC8 (SMEL_010g352650), a new class of phosphatase playing a role in vacuolar trafficking. By slightly expanding the region of interest, five genes (SMEL_010g352310, SMEL_010g352320, SMEL_010g352330, SMEL_010g352490 and SMEL_010g352500) were identified and annotated as having predicted 2-oxoglutarate/Fe(II)-dependent dioxygenase activity (ANS). In the same region, three sequences with homology with regulatory-associated protein of TOR (RAPTOR) are localized.

adlan10.1

The major QTL adlan10.1 lies at $236.99 \mathrm{cM}$ on E10, physically located at 94.9-95.08 Mb. A total of seven genes were identified as candidate, five of which were annotated as peroxidases or protein disulfide-isomerases.

stean 5.1, toan 5.2

The major QTL stean5.1 identified in the three environments as well as toan5.2, specific to $\mathrm{BT}$ and ML, underlined a region on E5 in the interval 36.0-36.3 Mb, containing twelve genes. Among them, a class II heat shock protein and a putative BHLH could represent a good candidate. By increasing the confidence interval to the physical position of the marker 3311_PstI_L361, the candidate SMEL_005g236240, annotated as an acetyl-CoA-benzylalcohol acetyltransferase, was found.

toan5.1-corcol5.1-hyan5.1

The major QTL toan5.1 as well as corcol5.1 identified in ML and BT and hyan5.1 in ML lean on E05, in a small region at $\sim 37.5 \mathrm{Mb}$. Among the seven annotated genes which lie in this interval, two genes annotated as BKI1 (BRI1 kinase inhibitor 1), are eligible as the best candidate. By slightly increasing the region analyzed, two scopoletin glucosyltransferases, as well as a cluster of three genes annotated as encoding cytochrome P450, two zinc fingers and a BHLH-like protein were spotted.

hyan7.1

The minor QTL for hyan7.1 lies on E07 at $83.94 \mathrm{cM}$, whose confidence interval physical region spanned between 132.76 and $134.02 \mathrm{Mb}$. More than 80 annotated genes were found, among which the most interesting are a cluster of putative candidates annotated as similar to MYB14-15-58-102, a PPC6-6 and a F-box/kelch-repeat protein.

stean 2.1

The minor QTL tean2.1 lies on E02 at about 30.5 Mbp. A total of five annotated genes were spotted, among which a L10 interacting MYB domain protein, a Heat shock $70 \mathrm{kDa}$ protein and an AKRP — ankyrin repeat domain-containing protein-are eligible as possible candidates.

\section{Discussion}

\subsection{Genetic Map Construction and Phenotyping}

Studies on eggplant genome organization have received an increasing amount of interest in the last few decades, turning it from a "genomic orphan species" to a crop with a high-quality genomic sequence available [36]. As in several other crops, the low level of polymorphism within the cultivated eggplant germplasm required huge efforts in detecting markers exploitable for linkage mapping purposes [61,62]. 
Several "first generation" inter-specific and intra-specific maps were developed, with the former exploiting a higher genetic polymorphism, but being of minor relevance for marker-assisted breeding [63]. QTLs associated to morphological and plant production traits, as well as parthenocarpy, resistances to fungal and bacterial wilts were identified through bi-parental approaches and genome-wide association (GWA) studies on the basis of the available linkage maps.

An intraspecific $\mathrm{F}_{2}$ segregating population, obtained from the same cross from which we developed the RIL population in the present study, proved to be a highly efficient tool for the detection of more than 140 QTLs associated to leaf, flower, plant and fruit traits, fruit biochemical composition and resistances to fungal wilts [22,28-31]. Our $\mathrm{F}_{7}$ RIL population was also previously used for anchoring the "67/3" eggplant genome sequence [36]. Here, we exploited the GBS-derived approach, as applied by Acquadro et al. [64] in eggplant, to develop a new high density linkage map including 7249 SNPs assigned to the 12 chromosomes and spanning $2169.23 \mathrm{cM}$. Its genetic length is longer than the previously published intra-specific maps $[14,22,24,28]$, as well as the one recently made available by Salgon et al. [34], which spans about $1500 \mathrm{cM}$ and includes 1170 markers.

The newly created map clearly represents a step forward compared to the one we developed for anchoring the genome [36]. This was generated using markers derived from an imputation-based method following low-coverage sequencing of the same mapping population. The pipeline took windows containing 100 SNPs along scaffolds to convert them into genetic markers, which were actually based on the haplotype of 100 SNPs.

This approach was useful in anchoring the scaffolds to pseudomolecules, but some drawbacks are present, especially for QTL analysis and candidate gene identification. Indeed, this contained three chromosomal locations (E02, E08 and E11), which were split into two different portions. The newly developed map actually includes 12 chromosomes, which in turn may increase the efficiency in identifying candidate regions during QTL analysis. Furthermore, the map developed in this study contains a slightly higher number of gaps shorter than $5 \mathrm{cM}$ than the previous one, but some chromosomes have a larger gap. On the other hand, the newly created map is shorter $(\sim 500 \mathrm{cM})$ and contains more markers (1285) (Table S2) than the previous one, resulting in a more dense and saturated map.

Finally, in the map used for anchoring the genome sequence, a marker is based on a window of 100 SNPs, whose size is dependent on the polymorphic level of that specific chromosome regions and whose coordinates in the genome are not well defined. On the contrary, in the new map, each marker is based on a single SNP, allowing us to know the precise position of each marker in the genome and make it possible for a breeder to identify the genes located in a QTL region on the basis the available annotation. Furthermore, GBS data provide information on the SNPs that generated the markers, which is of utility for more targeted analysis.

Our map contains about $24 \%$ distorted markers, presumably as a result of the genetic distance between the parents as well as possible preferential or gametic/zygotic selection occurring during the development of our RIL population. However, we included these markers in order to increase the genomic coverage of the genetic map, which reached about $96 \%$ of the physical sequence. Indeed, if properly handled, these markers do not cause detrimental effects and increase the potential of QTL mapping, as previously reported $[65,66]$. The breeding line '305E40', used as the female parent, contains scattered introgressed regions from S. aethiopicum, with a large portion on chromosome E02, which includes the locus Rfo-sa1 [29,45]. This may justify the reduced recombination observed not only on E02, but also E09 and E12.

All the anthocyanin-related traits showed a high $h^{2}$ BS (lowest value of $86 \%$ for lvean_BT) with a high correlation of their phenotypic value among different environments. Similar results were previously reported for some of the traits in the study in the $F_{2}$ population developed from the same cross [28,30]. Transgressive genotypes were infrequent and always deviated towards the less pigmented parent '305E 40 '. The parental line '305E40' produced less vigorous seeds, but about $25 \%$ of the RIL population showed a further reduction in the speed of seedling emergence; this is presumably 
also because we were not able to identify all the QTLs affecting this trait, implying that some other QTLs still remain to be identified.

Conventionally, a 'major' QTL is defined as such when, in addition to justifying a PVE greater than $10 \%$ [67], it is conserved in multiple seasons/locations [68-70]. We identified at least one major QTL for all the traits in study including hyan and sei, although in this case the traits were evaluated only in one environment.

\subsection{QTLs and Underlying Candidate Genes}

The least and the most convincing LOD scores associated with the major QTLs were 3.89 (sei2.2) and 37.70 (flian10.1_MT), respectively. The explained PVE varied from 10.4\% (sei2.1) up to $69.3 \%$ (flian10.1_MT), and most of the identified QTLs were stable across two/three environments, making them potentially useful for marker-assisted selection. On the other hand, some QTLs were identified in just one (corcol5.2_MT) or two (like corcol5.1 or stean2.1) environments. This suggests a strong environmental effect on their expression, but also that the rather limited genetic variation in the mapping population did not allow us to fully dissect the genetic bases of these traits [71].

\subsubsection{Seed Emergency Index}

Seed germination is the switch from a dormant embryonic state to a highly active phase of growing. It is also defined as the sum of events that begin with seed imbibition and culminate in the emergence of the embryonic axis (usually the radicle) from the seed coat [72,73]. This progression is controlled by several internal factors, such as auxins, abscisic acid (ABA), cytokinins, ethylene, and GA content and balance, as well as environmental factors that include water availability, temperature, and light [74]. Eggplant, as with most of the Solanum species, is mainly propagated by seeds, whose vigor influences their germination and seedling emergence performance. Seed dormancy, low uniformity and poor germination rate have been documented in many eggplant accessions as well as in wild and allied species, including those employed as rootstock or those useful for introgression breeding [11,75-79].

Here, we reported, for the first time, three QTLs associated to seed vigor in eggplant, assessed by evaluating the speed of emergence index. Only one major QTL was spotted, suggesting that other key regions controlling this trait are still to be identified.

However, interestingly, both a major and minor QTL (i.e., sei2.1 and sei2.2) were detected on chromosome E02, with sei2.1 inherited from the female parent '305E40'. As previously pointed out, this breeding line harbors on chromosome E02 an introgressed fragment from S. aethiopicum, [28,36], associated to the Fusarium oxysporum resistance locus Rfo-sa1 [45]. Thus, we could speculate that the introgressed portion of S. aethiopicum genome might be also involved in the genetic control of this trait, as this allied species usually displays a delayed germination with respect to eggplant.

The introgressed region may also be responsible of an inaccurate positioning of the genomic sequences in this region, and, consequently, in a reduction in the QTL mapping efficiency. Indeed, the candidate genes encompassing sei2.1 are physically located both at $48-54 \mathrm{Mb}$ and $9.2 \mathrm{Mb}$ on E02. In the first large region, a paired amphipathic helix protein Sin3-like 2 could be a good candidate gene as it belongs to a class of proteins, involved in the response to hormonal stimuli and in the seed dormancy breakdown [80], while the NHL6 genes identified at $9 \mathrm{Mb}$ have been reported to play an important role in the abiotic stress-induced abscisic acid (ABA) signaling and biosynthesis, acting as positive regulator of ABA-mediated seed germination inhibition [81].

Sei2. 2 overlies some candidates annotated as similar to previously described genes involved in the ABA response and seed dormancy breakdown: two membrane C2-domain abscisic acid-related proteins (CAR2) [82] and a GRDP1-glycine-rich domain-containing protein 1 [83]. Furthermore, two TCP1 encoding genes and a peptide methionine sulfoxide reductase should also be considered as similar genes are involved in the repair mechanism during seed dormancy release in Arabidopsis and the increase in $M$. truncatula seed longevity by reducing the protein oxidation damage [84,85], respectively. 
Several Serpins-ZX and NRT1/ PTR coding-genes were identified in the seit.1 region. The Serpin gene family has gained attention in wheat and barley for its role in grain development, but these genes could play a possible role in the mobilization of sugars during germination by enhancing $\beta$-amylase enzymatic activity and preventing $\beta$-amylase aggregation during oxidative stress [86]. The cluster of NPF6/NRT1-1 nitrate or di/tripeptide transporters, also spotted in sei4.1, are potentially involved in nitrate sensing and signaling $[87,88]$, and genes belonging to this class are reported to regulate seed development, germination and dormancy cycling in fava bean and Arabidopsis [89-91], with a possible involvement in the ABA transport [92]. Nitrate itself is reported as a signal molecule that controls several aspects of plant development including seed dormancy, as higher nitrate accumulation in mother plants leads to lower seed dormancy [93].

Good candidates for future studies might also be other genes in the same region encoding an Ent-kaurene oxidase and two B3 domain proteins, all involved in GA biosynthesis: the latter are regulating factors of the pathway in which the former is a key enzyme, and it is reported that suppressive mutations in the coding region of both genes cause a delay in seed germination and seedling development $[94,95]$.

\subsubsection{Anthocyanins}

Anthocyanins are among the most represented flavonoid compounds in plants and are responsible for the pigmentation of many flowers and fruits. They have an essential eco-physiological role in attracting pollinators and seed dispersers $[96,97]$ and are also implicated in the response against biotic and abiotic stresses $[98,99]$

The genetic control of anthocyanin formation, distribution and accumulation has been widely studied in Solanaceae species [38-43,100,101]. This was long thought to be a complex trait in eggplant, involving several loci with assumed epistatic interactions and/or pleiotropic effects [102,103]. More recently, QTL-related studies allowed us to identify the chromosome regions involved in anthocyanin distribution in eggplant tissues and organs, highlighting their synteny with tomato $[28,30,32,44]$ and, thanks to the recent availability of an high quality eggplant genome sequence coupled with metabolomic analyses [37], allowed us to localize putative candidate genes.

As previously observed [28,30,32], our ultra-high density genetic linkage map confirmed that the clusters on E10 and E05 are involved in the pigmentation of eggplant tissues, which may be associated with two different aspects of the anthocyanin synthesis among tissues, but likely control different processes linked to anthocyanin accumulation in diverse tissues. Indeed, the cluster on E10 is mainly prominent for anthocyanin production and accumulation in the vegetative plant organs, except in the corolla of the flower, whose pigmentation is governed by the major QTL on E5 with a smaller contribution by a minor QTL on E10. Conversely, the cluster on E05 contains QTLs more likely associated with the anthocyanin tonality (in flower, with frucol, and in general in all the vegetative tissues, represented by toan) and with the accumulation of anthocyanins in hypocotyl (hyan). Although the phenotypic data available for hyan were only collected in one environment, the combined results with stean QTLs seem to suggest that both 5 and 10 are involved, but with stronger specific effect on anthocyanin accumulation of hyan5.1 in the hypocotyl at plantlet stage and of stean10.1 in the stem of the fully developed plant. Overall, the joint effect of both E05 and E10 QTLs could impact on hyan, stean, corcol and toan through an interaction between genes, influencing both tonality and anthocyanin intensity.

\subsubsection{Anthocyanin Related Candidate Genes Identifications}

The biosynthesis of anthocyanin is one of the most studied pathways in plants, with most of the genes encoding for enzymes and regulatory transcription factors (TFs) identified in several plant species, including Solanaceae $[3,104]$. The anthocyanin pathway is under the control of many early (EBGs) or late (LBGs) biosynthetic genes, with the former involved in the first steps of biosynthesis of flavonols and other flavonoid compounds and the latter involved in the ensuing steps of the pathway 
until the final steps of decoration, leading to different anthocyanin compounds. Each enzymatic step of this complex pathway is finely tuned by co-activators independent and functionally redundant R2R3-MYB regulatory proteins which regulate the expression of structural genes, alone or in complexes with other TFs belonging to the basic helix-loop-helix (BHLH) family. The control of the biosynthetic pathway is strongly dependent on tissue, developmental stage and environment, and has only been partially elucidated in eggplant with regard solely to the fruit peel coloration [36,103,105-108].

\section{Cluster on Chromosome E10}

The cluster identified on E10 lies in a region of $1.5 \mathrm{Mb}$, between 93.5 and $95 \mathrm{Mb}$, containing three clusters of colocalizing QTLs.

We spotted, next to the upper limit of the cluster and close to toan, five genes predicted as ANS, which might be involved in the oxidation of leucocyanidin, in the second to last step of anthocyanin biosynthesis [109]. A further characterization highlighted that these genes are located in a genomic region of the parental line '67-3' containing retrotransposon-like sequences, which could alter the expression pattern of nearby genes [110]. Within the QTL for toan at $232.77 \mathrm{cM}$, we identified a putative MYB transcription factor and a phosphoinositide phosphatase, belonging to a class of phosphatases that plays a key role in abiotic stress response, vacuolar trafficking and anthocyanin accumulation [111].

Lying within stean10.1, we identified an ankyrin repeat-containing protein coding gene together with a dehydration-responsive element-binding protein $2 \mathrm{C}$ and a PPC6-1 (protein phosphatase 2C). Ankyrin repeat proteins were reported to be involved in the anthocyanin synthesis pathway [112], while the other two candidates are putatively involved in the response to abiotic stresses and detoxification [113]. Finally, alongside adlan10.1, we identified five peroxidases coding genes which may be involved in the degradation of anthocyanin, influencing the overall coloration of the tissues where they are expressed. Indeed, enzymatic degradation has been considered to be responsible for anthocyanin breakdown in plants, leading to pigment concentration reduction and colour fading [114]. Recent studies have shown that PODs and laccases (LACs) are responsible for anthocyanin catalysis [115, 116], and also, in combination with some environmental factors, such as high temperature and low light density, were reported to enhance the peroxidase activity [104,117].

\section{QTL cluster on Chromosome E05}

The region identified on E05 which controls stean, toan, hyan and corcol contains two slightly separate clusters. The upper region, including the QTLs for toan5.2 and stean5.1, was already spotted by Barchi et al. [28] as a genomic region involved in the control of several anthocyanin-related traits (such as stean) and the corolla color. In the same position, Toppino et al. [30] mapped QTLs associated to peel fruit color as well as to the presence and amount (determined by HPLC) of D3R and nasunin, the two different anthocyanins in the eggplant peel. Analogous QTLs in the distal portion of E05 were also previously identified by GWAS approaches [32,44].

Our candidate gene search highlighted the presence of an acetyl-CoA-benzylalcohol acetyltransferase (AAT), for which we speculate a function in the aromatic group decoration as the last step of the anthocyanin biosynthetic pathway. Furthermore, the distribution and dominance relationships strongly support the hypothesis that AAT is active in '67/3' and inactive in '305E40', and thus responsible of the acetylation of the D3R glucosidic group [118] and the subsequent conversion into nasunin. The comparison of the Illumina sequencing data available for the two parental lines [36] revealed a $1 b p$ indel which could determine a loss-of-function mutation in the 305E40_AAT CDS sequence, opening the path to a deeper functional study of this gene.

The cluster of QTLs for corcol, hyan and toan on E5 is proximal to toan5.1 and stean; in this region, two scopoletin glucosyltransferase coding genes, involved in the phenylpropanoid pathways [119], were spotted, alongside four genes annotated as cytochrome P450, known as playing pivotal roles in the biosynthesis of plant secondary metabolites, including phenylpropanoids and phytoalexins [120,121]. 


\section{QTLs for hyan7.1 and stean2.1}

In the hyan7.1 region, a cluster of MYB genes were identified, with homology to sequences known to be involved in the phenylpropanoid pathway and more specifically in the stilbene biosynthesis in Vitis [122], lignin in Arabidopsis [123] and anthocyanin in forage legumes [124]. In the same region, other interesting candidate genes are a PPC6-6 (probable protein phosphatase 2C) and a F-box/kelch-repeat protein, a class of regulators reported to be associated to phenylpropanoid pathway [125].

Finally, for stean2.1, a valid candidate gene was an AKRP—ankyrin repeat domain-containing protein - which was reported to be involved in the anthocyanin synthesis pathway [112].

\section{Conclusions}

Our results demonstrate that the newly developed map, supported by genome annotation, supplies a key tool to gather valuable information for QTL fine mapping, candidate gene identification, and for the development of molecular markers suitable for identifying favorable alleles, and thus increasing the precision and efficiency of selection in breeding. Our high-density intraspecific map made it possible not only to validate previously reported QTLs, but also to identify new ones associated with the plant anthocyanin pigmentation intensity and tonality, as well as to better define their underlying chromosomal regions. Thanks to the availability of genome annotation, it was also possible to provide a set of relevant candidate genes involved in the anthocyanin biosynthetic process and regulation, some of which are already the subject of ongoing studies.

Finally, the map allowed us to identify the first QTLs affecting seed vigor in eggplant, as measured by the speed of seedling emergence from soil. The identification of the genetic bases of this trait are of key importance, since seed germination and seedling emergence represent two of the most vulnerable phases of a crop cultivation cycle, and less vigorous seeds, other than reducing the crop competitiveness toward weeds, increase the exposure of seedlings to abiotic (drought, heat) and biotic (soil-borne pests) stresses. On the whole, the QTLs we detected provide important knowledge on the genomic region linked physiological and phenotypic properties in eggplant which may be usefully exploited in future breeding programs.

Supplementary Materials: The following are available online at http://www.mdpi.com/2073-4425/11/7/745/s1, Figure S1: Distribution of sequenced reads, after quality cleaning and trimming procedures, across the parental lines and $F_{1}$ (first three samples) as well as the RIL mapping population (in million reads); Figure S2: Eggplant linkage map. Marker names are shown to the right of each chromosome, with map distances (in cM) shown on the left; Figure S3: Heat map representing pairwise recombination fractions with LOD scores for each marker on all 12 chromosomes; Figure S4: Marey Map plots of SNPs mapped to positions on the 12 S. melongena chromosomes vs. their physical positions on the v3. eggplant pseudomolecules from Barchi et al. [36]; Table S1: Markers name, chromosome, genetic position of all markers on the map and RILS graphical haplotypes are reported. The color 'orange' represents homozygous alleles from the "305E40" parent, 'blue' represent homozygous alleles from "67/3" parent, 'green' as heterozygous alleles and white as missing data; Table S2: Parameters associated with the eggplant genetic map compared to the previous developed by Barchi et al. [36].

Author Contributions: Conceptualization, F.M., F.S., S.L. and G.L.R.; Data curation, L.B.; Formal analysis, L.B., M.M. and E.P.; Funding acquisition, L.T., F.C., E.P. and G.L.R.; Investigation, L.T., L.B., F.M., N.A., D.P., S.G., T.S., S.F., A.M., T.C. and G.L.R.; Visualization, L.T., L.B. and E.P.; Writing-original draft, L.T., L.B. and M.M.; Writing-review \& editing, F.M., F.C., E.P., F.S., S.L. and G.L.R. All authors have read and agreed to the published version of the manuscript.

Funding: This work was partially funded by the European Union's Horizon 2020 Research and Innovation Program under the Grant Agreement number 677379 (G2P-SOL project: 'linking genetic resources, genomes and phenotypes of solanaceous crops') and by CARIPLO Foundation in the frame of the project Code 2016-0723 (WAKEAPT project: 'Seed Wake-up with Aptamers: a New Technology for Dormancy Release and Improved Seed Priming').

Conflicts of Interest: The authors declare no conflict of interest. 


\section{References}

1. Fukuoka, H.; Yamaguchi, H.; Nunome, T.; Negoro, S.; Miyatake, K.; Ohyama, A. Accumulation, functional annotation, and comparative analysis of expressed sequence tags in eggplant (Solanum melongena L.), the third pole of the genus Solanum species after tomato and potato. Gene 2010, 450, 76-84. [CrossRef] [PubMed]

2. Hirakawa, H.; Shirasawa, K.; Miyatake, K.; Nunome, T.; Negoro, S.; Ohyama, A.; Yamaguchi, H.; Sato, S.; Isobe, S.; Tabata, S.; et al. Draft genome sequence of eggplant (Solanum melongena L.): The representative solanum species indigenous to the old world. DNA Res. Int. J. Rapid Publ. Rep. Genes Genomes 2014, 21, 649-660. [CrossRef]

3. Albert, V.A.; Chang, T.H. Evolution of a hot genome. Proc. Natl. Acad. Sci. USA 2014, 111, 5069-5070. [CrossRef] [PubMed]

4. Lester, R.N.; Hasan, S.M.Z. Origin and Domestication of the Brinjal Eggplant, Solanum Melongena, from S. incanum, in Africa and Asia. In Solanaceae III: Taxonomy, Chemistry, and Evolution; Hawkes, J.G., Lester, R.N., Nee, M., Estrada, N., Eds.; Royal Botanic Gardens: Kew, UK, 1991; pp. 369-387.

5. Meyer, R.S.; Karol, K.G.; Little, D.P.; Nee, M.H.; Litt, A. Phylogeographic relationships among Asian eggplants and new perspectives on eggplant domestication. Mol. Phylogenetics Evol. 2012, 63, 685-701. [CrossRef] [PubMed]

6. Cericola, F.; Portis, E.; Toppino, L.; Barchi, L.; Acciarri, N.; Ciriaci, T.; Sala, T.; Rotino, G.L.G.L.; Lanteri, S. The Population Structure and diversity of eggplant from Asia and the Mediterranean Basin. PLoS ONE 2013, 8, e73702. [CrossRef] [PubMed]

7. Page, A.; Gibson, J.; Meyer, R.S.; Chapman, M.A. Eggplant domestication: Pervasive gene flow, feralization, and transcriptomic divergence. Mol. Biol. Evol. 2019, 36, 1359-1372. [CrossRef]

8. FAO. Available online: http://faostat3.fao.org/home/E.org/ (accessed on 1 June 2020).

9. Zhang, Y.; Liu, H.; Shen, S.; Zhang, X. Improvement of eggplant seed germination and seedling emergence at low temperature by seed priming with incorporation SA into KNO 3 solution. Front. Agric. China 2011, 5, 534-537. [CrossRef]

10. Gisbert, C.; Prohens, J.; Nuez, F. Treatments for improving seed germination in eggplant and related species. Acta Hortic. 2009, 898, 45-51. [CrossRef]

11. Forti, C.; Ottobrino, V.; Bassolino, L.; Toppino, L.; Rotino, G.L.; Pagano, A.; Macovei, A.; Balestrazzi, A. Molecular dynamics of pre-germinative metabolism in primed eggplant (Solanum melongena L.) seeds. Hortic. Res. 2020, 7, 87. [CrossRef]

12. Doganlar, S.; Frary, A.; Daunay, M.C.; Lester, R.N.; Tanksley, S.D. A comparative genetic linkage map of eggplant (Solanum melongena) and its implications for genome evolution in the Solanaceae. Genetics 2002, 161, 1697-1711.

13. Doğanlar, S.; Frary, A.; Daunay, M.-C.; Huvenaars, K.; Mank, R.; Frary, A. High resolution map of eggplant (Solanum melongena) reveals extensive chromosome rearrangement in domesticated members of the Solanaceae. Euphytica 2014, 1-11. [CrossRef]

14. Wu, F.N.; Eannetta, N.T.; Xu, Y.M.; Tanksley, S.D. A detailed synteny map of the eggplant genome based on conserved ortholog set II (COSII) markers. Theor. Appl. Genet. 2009, 118, 927-935. [CrossRef]

15. Frary, A.; Doganlar, S.; Daunay, M.C.; Tanksley, S.D. QTL analysis of morphological traits in eggplant and implications for conservation of gene function during evolution of solanaceous species. Theor. Appl. Genet. 2003, 107, 359-370. [CrossRef]

16. Frary, A.; Frary, A.; Daunay, M.-C.; Huvenaars, K.; Mank, R.; Doğanlar, S. QTL hotspots in eggplant (Solanum melongena) detected with a high resolution map and CIM analysis. Euphytica 2014, 197, 211-228. [CrossRef]

17. Gramazio, P.; Prohens, J.; Plazas, M.; Andújar, I.; Herraiz, F.J.; Castillo, E.; Knapp, S.; Meyer, R.S.; Vilanova, S. Location of chlorogenic acid biosynthesis pathway and polyphenol oxidase genes in a new interspecific anchored linkage map of eggplant. BMC Plant Biol. 2014, 14, 350. [CrossRef] [PubMed]

18. Sunseri, F.; Sciancalepore, A.; Martelli, G.; Acciarri, N.; Rotino, G.L.; Valentino, D.; Tamietti, G. Development of RAPD-AFLP Map of Eggplant and Improvement of Tolerance to Verticillium Wilt. In Proceedings of the Acta Horticulturae, Leuven, Belgium, 30 September 2003; pp. 107-115.

19. Nunome, T.; Ishiguro, K.; Yoshida, T.; Hirai, M. Mapping of fruit shape and color development traits in eggplant (Solanum melongena L.) based on RAPD and AFLP markers. Breed. Sci. 2001, 51, 19-26. [CrossRef] 
20. Nunome, T.; Suwabe, K.; Iketani, H.; Hirai, M. Identification and characterization of microsatellites in eggplant. Plant Breed. 2003, 122, 256-262. [CrossRef]

21. Nunome, T.; Negoro, S.; Kono, I.; Kanamori, H.; Miyatake, K.; Yamaguchi, H.; Ohyama, A.; Fukuoka, H. Development of SSR markers derived from SSR-enriched genomic library of eggplant (Solanum melongena L.). Theor. Appl. Genet. 2009, 119, 1143-1153. [CrossRef]

22. Barchi, L.; Lanteri, S.; Portis, E.; Stàgel, A.; Valè, G.; Toppino, L.; Leonardo Rotino, G. Segregation distortion and linkage analysis in eggplant (Solanum melongena L.). Genome 2010, 53. [CrossRef]

23. Fukuoka, H.; Miyatake, K.; Nunome, T.; Negoro, S.; Shirasawa, K.; Isobe, S.; Asamizu, E.; Yamaguchi, H.; Ohyama, A. Development of gene-based markers and construction of an integrated linkage map in eggplant by using Solanum orthologous (SOL) gene sets. Theor. Appl. Genet. 2012, 125, 47-56. [CrossRef]

24. Miyatake, K.; Saito, T.; Negoro, S.; Yamaguchi, H.; Nunome, T.; Ohyama, A.; Fukuoka, H. Development of selective markers linked to a major QTL for parthenocarpy in eggplant (Solanum melongena L.). Theor. Appl. Genet. 2012, 124, 1-11. [CrossRef]

25. Miyatake, K.; Saito, T.; Negoro, S.; Yamaguchi, H.; Nunome, T.; Ohyama, A.; Fukuoka, H. Detailed mapping of a resistance locus against Fusarium wilt in cultivated eggplant (Solanum melongena). Theor. Appl. 2016, 129, 357-367. [CrossRef] [PubMed]

26. Barchi, L.; Lanteri, S.; Portis, E.; Acquadro, A.; Valè, G.; Toppino, L.; Rotino, G.L.G.L.L.G.L.; Vale, G.; Toppino, L.; Rotino, G.L.G.L.L.G.L.; et al. Identification of SNP and SSR markers in eggplant using RAD tag sequencing. BMC Genom. 2011, 12. [CrossRef]

27. Baird, N.A.; Etter, P.D.; Atwood, T.S.; Currey, M.C.; Shiver, A.L.; Lewis, Z.A.; Selker, E.U.; Cresko, W.A.; Johnson, E.A. Rapid SNP Discovery and Genetic Mapping Using Sequenced RAD Markers. PLoS ONE 2008, 3, e3376. [CrossRef] [PubMed]

28. Barchi, L.; Lanteri, S.; Portis, E.; Valè, G.; Volante, A.; Pulcini, L.; Ciriaci, T.; Acciarri, N.; Barbierato, V.; Toppino, L.; et al. A RAD tag derived marker based eggplant linkage map and the location of QTLs determining anthocyanin pigmentation. PLoS ONE 2012, 7, e43740. [CrossRef] [PubMed]

29. Portis, E.; Barchi, L.; Toppino, L.; Lanteri, S.; Acciarri, N.; Felicioni, N.; Fusari, F.; Barbierato, V.; Cericola, F.; Valè, G.; et al. QTL mapping in eggplant reveals clusters of yield-related loci and orthology with the tomato genome. PLoS ONE 2014, 9, e89499. [CrossRef] [PubMed]

30. Toppino, L.; Barchi, L.; Lo Scalzo, R.; Palazzolo, E.; Francese, G.; Fibiani, M.; D' Alessandro, A.; Papa, V.; Laudicina, V.A.; Sabatino, L.; et al. Mapping Quantitative Trait Loci Affecting Biochemical and Morphological Fruit Properties in Eggplant (Solanum melongena L.). Front. Plant Sci. 2016. [CrossRef]

31. Barchi, L.; Toppino, L.; Valentino, D.; Bassolino, L.; Portis, E.; Lanteri, S.; Rotino, G.L. QTL analysis reveals new eggplant loci involved in resistance to fungal wilts. Euphytica 2018, 214, 20. [CrossRef]

32. Cericola, F.; Portis, E.; Lanteri, S.; Toppino, L.; Barchi, L.; Acciarri, N.; Pulcini, L.; Sala, T.; Rotino, G.L. Linkage disequilibrium and genome-wide association analysis for anthocyanin pigmentation and fruit color in eggplant. BMC Genom. 2014, 15, 896. [CrossRef]

33. Portis, E.; Cericola, F.; Barchi, L.; Toppino, L.; Acciarri, N.; Pulcini, L.; Sala, T.; Lanteri, S.; Rotino, G.L. Association mapping for fruit, plant and leaf morphology traits in eggplant. PLoS ONE 2015, 10, e0135200. [CrossRef]

34. Salgon, S.; Raynal, M.; Lebon, S.; Baptiste, J.M.; Daunay, M.C.; Dintinger, J.; Jourda, C. Genotyping by sequencing highlights a polygenic resistance to ralstonia pseudosolanacearum in eggplant (Solanum melongena L.). Int. J. Mol. Sci. 2018, 19, 357. [CrossRef] [PubMed]

35. Wei, Q.; Wang, W.; Hu, T.; Hu, H.; Wang, J.; Bao, C. Construction of a SNP-based genetic map using SLAF-Seq and QTL analysis of morphological traits in eggplant. Front. Genet. 2020, 11, 178. [CrossRef]

36. Barchi, L.; Pietrella, M.; Venturini, L.; Minio, A.; Toppino, L.; Acquadro, A.; Andolfo, G.; Aprea, G.; Avanzato, C.; Bassolino, L.; et al. A chromosome-anchored eggplant genome sequence reveals key events in Solanaceae evolution. Sci. Rep. 2019, 9, 11769. [CrossRef] [PubMed]

37. Sulli, M.; Barchi, L.; Francese, G.; Toppino, L.; Diretto, G.; Mennella, G.; Lanteri, S.; Rotino, G.; Giuliano, G. Metabolic Profiling of a Recombinant Inbred Eggplant Population Reveals Key Metabolic QTLs controlling Fruit Nutritional Quality. In Proceedings of the Plant \& Animal Genome XXVII Conference (pe0948), San Diego, CA, USA, 12-16 January 2019. 
38. Van Eck, H.J.; Jacobs, J.M.E.; Dijk, J.; Stiekema, W.J.; Jacobsen, E. Identification and mapping of three flower colour loci of potato (S. tuberosum L.) by RFLP analysis. Theor. Appl. Genet. 1993, 86, 295-300. [CrossRef] [PubMed]

39. Chaim, A.B.C.; Borovsky, Y.B.; De Jong, W.D.J.; Paran, I.P. Linkage of the $A$ locus for the presence of anthocyanin and $f_{s} 10.1$, a major fruit-shape QTL in pepper. Theor. Appl. Genet. 2003, 106, 889-894. [CrossRef]

40. Van Eck, H.J.; Jacobs, J.M.E.; van den Berg, P.M.M.M.; Stiekema, W.J.; Jacobsen, E. The inheritance of anthocyanin pigmentation in potato (Solanum tuberosum L.) and mapping of tuber skin colour loci using RFLPs. Heredity 1994, 73, 410-421. [CrossRef]

41. Borovsky, Y.; Oren-Shamir, M.; Ovadia, R.; De Jong, W.; Paran, I. The $A$ locus that controls anthocyanin accumulation in pepper encodes a $M Y B$ transcription factor homologous to Anthocyanin2 of Petunia. Theor. Appl. Genet. 2004, 109, 23-29. [CrossRef]

42. Bovy, A.; Schijlen, E.; Hall, R. Metabolic engineering of flavonoids in tomato (Solanum lycopersicum): The potential for metabolomics. Metabolomics 2007, 3, 399-412. [CrossRef]

43. Gonzali, S.; Mazzucato, A.; Perata, P. Purple as a tomato: Towards high anthocyanin tomatoes. Trends Plant Sci. 2009, 14, 237-241. [CrossRef]

44. Ge, H.; Liu, Y.; Jiang, M.; Zhang, J.; Han, H.; Chen, H. Analysis of genetic diversity and structure of eggplant populations (Solanum melongena L.) in China using simple sequence repeat markers. Sci. Hortic. 2013, 162, 71-75. [CrossRef]

45. Toppino, L.; Vale, G.; Rotino, G.L. Inheritance of Fusarium wilt resistance introgressed from Solanum aethiopicum Gilo and Aculeatum groups into cultivated eggplant (S.melongena) and development of associated PCR-based markers. Mol. Breed. 2008, 22, 237-250. [CrossRef]

46. Doyle, J.J.; Doyle, J.L. Isolation of plant DNA from fresh tissue. Focus 1990, 12, 13-14.

47. Acquadro, A.; Lanteri, S.; Scaglione, D.; Arens, P.; Vosman, B.; Portis, E. Genetic mapping and annotation of genomic microsatellites isolated from globe artichoke. Theor. Appl. Genet. 2009, 118, 1573-1587. [CrossRef]

48. Acquadro, A.; Barchi, L.; Gramazio, P.; Portis, E.; Vilanova, S.; Comino, C.; Plazas, M.; Prohens, J.; Lanteri, S. Coding SNPs analysis highlights genetic relationships and evolution pattern in eggplant complexes. PLoS ONE 2017, 12, e0180774. [CrossRef] [PubMed]

49. Li, H. Aligning Sequence Reads, Clone Sequences and Assembly Contigs with BWA-MEM. arXiv 2013, arXiv:1303.3997.

50. Li, H. A statistical framework for SNP calling, mutation discovery, association mapping and population genetical parameter estimation from sequencing data. Bioinform. 2011, 27, 2987-2993. [CrossRef]

51. Broman, K.W.; Wu, H.; Sen, S.; Churchill, G.A.; Sen, Ś; Churchill, G.A.; Sen, S.; Churchill, G.A. R/qtl: QTL mapping in experimental crosses. Bioinformatics 2003, 19, 889-890. [CrossRef]

52. Van Ooijen, J.W. JoinMap ß4, Software for the Calculation of Genetic Linkage Maps in Experimental Populations; Kyazma BV: Wageningen, The Netherlands, 2006.

53. Van Os, H.; Stam, P.; Visser, R.G.F.; van Eck, H.J. SMOOTH: A statistical method for successful removal of genotyping errors from high-density genetic linkage data. Theor. Appl. Genet. 2005, 112, 187-194. [CrossRef]

54. Voorrips, R.E. MapChart: Software for the graphical presentation of linkage maps and QTLs. J. Hered. 2002, 93, 77-78. [CrossRef]

55. R Core Team. R: A Language and Environment for Statistical Computing; R Foundation for Statistical Computing. 2020. Available online: https://www.r-project.org/ (accessed on 15 May 2020).

56. Jansen, R.C. Interval mapping of multiple quantitative trait loci. Genetics 1993, 135, 205-211.

57. Jansen, R.C.; Stam, P. High-resolution of quantitative traits into multiple loci via interval mapping. Genetics 1994, 136, 1447-1455. [PubMed]

58. Van Ooijen, J.W. MapQTL 5, Software for the Mapping of Quantitative Trait Loci in Experimental Populations; Kyazma BV: Wageningen, The Netherlands, 2004; Volume 63.

59. Churchill, G.A.; Do erge, R.W. Empirical Threshold Values for Quantitative Trait Mapping. Genetics 1994, 138, 963-971. [PubMed]

60. CMplot. Available online: https://github.com/YinLiLin/R-CMplot (accessed on 15 June 2020).

61. Stàgel, A.; Portis, E.; Toppino, L.; Rotino, G.L.; Lanteri, S. Gene-based microsatellite development for mapping and phylogeny studies in eggplant. BMC Genom. 2008, 9, 357. [CrossRef] [PubMed] 
62. Barchi, L.; Acquadro, A.; Alonso, D.; Aprea, G.; Bassolino, L.; Demurtas, O.; Ferrante, P.; Gramazio, P.; Mini, P.; Portis, E.; et al. Single Primer Enrichment Technology (SPET) for high-throughput genotyping in tomato and eggplant germplasm. Front. Plant Sci. 2019, 10, 1005. [CrossRef] [PubMed]

63. Barchi, L.; Portis, E.; Toppino, L.; Rotino, G.L. Molecular Mapping, QTL Identification, and GWA Analysis. In The Eggplant Genome; Springer International Publishing: Cham, Switzerland, 2019; pp. 41-54.

64. Acquadro, A.; Barchi, L.; Portis, E.; Mangino, G.; Valentino, D.; Mauromicale, G.; Lanteri, S. Genome reconstruction in Cynara cardunculus taxa gains access to chromosome-scale DNA variation. Sci. Rep. 2017, 7, 5617. [CrossRef]

65. Zhang, X.F.; Wang, G.Y.; Dong, T.T.; Chen, B.; Du, H.S.; Li, C.B.; Zhang, F.L.; Zhang, H.Y.; Xu, Y.; Wang, Q.; et al. High-density genetic map construction and QTL mapping of first flower node in pepper (Capsicum annuum L.). BMC Plant Biol. 2019, 19, 167. [CrossRef]

66. Hu, X.H.; Zhang, S.Z.; Miao, H.R.; Cui, F.G.; Shen, Y.; Yang, W.Q.; Xu, T.T.; Chen, N.; Chi, X.Y.; Zhang, Z.M.; et al. High-density genetic map construction and identification of QTLs controlling oleic and linoleic acid in peanut using SLAF-seq and SSRs. Sci. Rep. 2018, 8, 1-10. [CrossRef]

67. Collard, B.; Jahufer, M.; Brouwer, J.; Pang, E. An introduction to markers, quantitative trait loci (QTL) mapping and marker-assisted selection for crop improvement: The basic concepts. Euphytica 2005, 142, 169-196. [CrossRef]

68. Li, Z.; Jakkula, L.; Hussey, R.S.; Tamulonis, J.P.; Boerma, H.R. SSR mapping and confirmation of the QTL from PI96354 conditioning soybean resistance to southern root-knot nematode. Theor. Appl. Genet. 2001, 103, 1167-1173. [CrossRef]

69. Lindhout, P. The perspectives of polygenic resistance in breeding for durable disease resistance. Euphytica 2002, 124, 217-226. [CrossRef]

70. Pilet-Nayel, M.P.-N.; Muehlbauer, F.M.; McGee, R.M.; Kraft, J.K.; Baranger, A.B.; Coyne, C.C. Quantitative trait loci for partial resistance to Aphanomyces root rot in pea. Theor. Appl. Genet. 2002, 106, 28-39. [CrossRef] [PubMed]

71. Lander, E.S.; Botstein, D. Mapping mendelian factors underlying quantitative traits using RFLP linkage maps. Genetics 1989, 121, 185-199. [PubMed]

72. Nonogaki, H.; Bassel, G.W.; Bewley, J.D. Germination-still a mystery. Plant Sci. 2010, 179, 574-581. [CrossRef]

73. Weitbrecht, K.; Müller, K.; Leubner-Metzger, G. First off the mark: Early seed germination. J. Exp. Bot. 2011, 62, 3289-3309. [CrossRef]

74. Rajjou, L.; Duval, M.; Gallardo, K.; Catusse, J.; Bally, J.; Job, C.; Job, D. Seed Germination and Vigor. Annu. Rev. Plant Biol. 2012, 63, 507-533. [CrossRef]

75. Adebola, P.O.; Afolayan, A.J. Germination responses of Solanum aculeastrum, a medicinal species of the Eastern Cape, South Africa. Seed Sci. Technol. 2006, 34, 735-740. [CrossRef]

76. Demir, I.; Ermis, S.; Okçu, G.; Matthews, S. Vigour tests for predicting seedling emergence of aubergine (Solanum melongena L.) seed lots. Seed Sci. Technol. 2005, 33, 481-484. [CrossRef]

77. Joshua, A. Seed germination of Solanum incanum: An example of germination programs of tropical vegetable crops. Acta Hortic. 1977, 83, 155-162. [CrossRef]

78. Ibrahim, M.; Munira, M.K.; Kabir, M.S.; Islam, A.K.M.S.; Miah, M.M.U. Seed germination and graft compatibility of wild solanum as rootstock of tomato. J. Biol. Sci. 2001, 1, 701-703. [CrossRef]

79. Taab, A.; Andersson, L. Seed dormancy dynamics and germination characteristics of Solanum nigrum. Weed Res. 2009, 49, 490-498. [CrossRef]

80. Wang, Z.; Cao, H.; Sun, Y.; Li, X.; Chen, F.; Carles, A.; Li, Y.; Ding, M.; Zhang, C.; Deng, X.; et al. Arabidopsis paired amphipathic helix proteins SNL1 and SNL2 redundantly regulate primary seed dormancy via abscisic acid-ethylene antagonism mediated by histone deacetylation. Plant Cell 2013, 25, 149-166. [CrossRef]

81. Bao, Y.; Song, W.M.; Pan, J.; Jiang, C.M.; Srivastava, R.; Li, B.; Zhu, L.Y.; Su, H.Y.; Gao, X.S.; Liu, H.; et al. Overexpression of the NDR1/HIN1-Like gene NHL6 modifies seed germination in response to abscisic acid and abiotic stresses in Arabidopsis. PLoS ONE 2016, 11. [CrossRef]

82. Lockhart, J. Membrane bound: C2-domain abscisic acid-related proteins help abscisic acid receptors get where they need to go. Plant Cell 2014, 26, 4566. [CrossRef]

83. Rodríguez-Hernández, A.A.; Ortega-Amaro, M.A.; Delgado-Sánchez, P.; Salinas, J.; Jiménez-Bremont, J.F. AtGRDP1 Gene Encoding a Glycine-Rich domain protein is involved in germination and responds to ABA Signalling. Plant Mol. Biol. Report. 2014, 32, 1187-1202. [CrossRef] 
84. Arc, E.; Chibani, K.; Grappin, P.; Jullien, M.; Godin, B.; Cueff, G.; Valot, B.; Balliau, T.; Job, D.; Rajjou, L. Cold stratification and exogenous nitrates entail similar functional proteome adjustments during Arabidopsis seed dormancy release. J. Proteome Res. 2012, 11, 5418-5432. [CrossRef]

85. Chatelain, E.; Hundertmark, M.; Leprince, O.; Gall, S.L.; Satour, P.; Deligny-Penninck, S.; Rogniaux, H.; Buitink, J. Temporal profiling of the heat-stable proteome during late maturation of Medicago truncatula seeds identifies a restricted subset of late embryogenesis abundant proteins associated with longevity. Plant Cell Environ. 2012, 35, 1440-1455. [CrossRef] [PubMed]

86. Cohen, M.; Davydov, O.; Fluhr, R. Plant serpin protease inhibitors: Specificity and duality of function. J. Exp. Bot. 2019, 70, 2077-2085. [CrossRef]

87. Tsay, Y.F.; Chiu, C.C.; Tsai, C.B.; Ho, C.H.; Hsu, P.K. Nitrate transporters and peptide transporters. FEBS Lett. 2007, 581, 2290-2300. [CrossRef] [PubMed]

88. Ho, C.H.; Lin, S.H.; Hu, H.C.; Tsay, Y.F. CHL1 functions as a nitrate sensor in plants. Cell 2009, 138, $1184-1194$. [CrossRef]

89. Miranda, M.; Borisjuk, L.; Tewes, A.; Dietrich, D.; Rentsch, D.; Weber, H.; Wobus, U. Peptide and amino acid transporters are differentially regulated during seed development and germination in faba bean. Plant Physiol. 2003, 132, 1950-1960. [CrossRef]

90. Footitt, S.; Huang, Z.; Clay, H.A.; Mead, A.; Finch-Savage, W.E. Temperature, light and nitrate sensing coordinate Arabidopsis seed dormancy cycling, resulting in winter and summer annual phenotypes. Plant $J$. 2013, 74, 1003-1015. [CrossRef] [PubMed]

91. Osuna, D.; Prieto, P.; Aguilar, M. Control of seed germination and plant development by carbon and nitrogen availability. Front. Plant Sci. 2015, 6, 1023. [CrossRef] [PubMed]

92. Kanno, Y.; Hanada, A.; Chiba, Y.; Ichikawa, T.; Nakazawa, M.; Matsui, M.; Koshiba, T.; Kamiya, Y.; Seo, M. Identification of an abscisic acid transporter by functional screening using the receptor complex as a sensor. Proc. Natl. Acad. Sci. USA 2012, 109, 9653-9658. [CrossRef]

93. Alboresi, A.; Gestin, C.; Leydecker, M.T.; Bedu, M.; Meyer, C.; Truong, H.N. Nitrate, a signal relieving seed dormancy in Arabidopsis. Plant Cell Environ. 2005, 28, 500-512. [CrossRef] [PubMed]

94. Guo, X.; Hou, X.; Fang, J.; Wei, P.; Xu, B.; Chen, M.; Feng, Y.; Chu, C. The rice GERMINATION DEFECTIVE 1, encoding a B3 domain transcriptional repressor, regulates seed germination and seedling development by integrating GA and carbohydrate metabolism. Plant J. 2013, 75, 403-416. [CrossRef] [PubMed]

95. Zhang, H.; Li, M.; He, D.; Wang, K.; Yang, P. Mutations on ent-kaurene oxidase 1 encoding gene attenuate its enzyme activity of catalyzing the reaction from ent-kaurene to ent-kaurenoic acid and lead to delayed germination in rice. PLoS Genet. 2020, 16, e1008562. [CrossRef]

96. Harborne, J.B.; Williams, C.A. Advances in flavonoid research since 1992. Phytochemistry 2000, 55, 481-504. [CrossRef]

97. Schemske, D.W.; Bradshaw, H.D. Pollinator preference and the evolution of floral traits in monkeyflowers (Mimulus). Proc. Natl. Acad. Sci. USA 1999, 96, 11910-11915. [CrossRef]

98. Close, D.C.; Beadle, C.L. The Ecophysiology of foliar anthocyanin. Bot. Rev. 2003, 69, 149-161. [CrossRef]

99. Gross, J. Pigments in Vegetables: Chlorophylls and Carotenoids; Springer Science \& Business Media: New York, NY, USA, 2012; ISBN 1461520339.

100. De Jong, W.S.; Eannetta, N.T.; Jong, D.M.; Bodis, M. Candidate gene analysis of anthocyanin pigmentation loci in the Solanaceae. Theor. Appl. Genet. 2004, 108, 423-432. [CrossRef]

101. Stommel, J.R.; Dumm, J.M. Coordinated regulation of biosynthetic and regulatory genes coincides with anthocyanin accumulation in developing eggplant fruit. J. Amer. Soc. Hort. Sci. 2015, 140, 129-135. [CrossRef]

102. Tatebe, T. On inheritance of color in Solanum melongena L. Jpn. J. Genet. 1939, 15, 261-271. [CrossRef]

103. Tigchelaar, E.C.; Janick, J.; Erickson, H.T. The genetics of anthocyanin coloration in eggplant (Solanum melongena L.). Genetics 1968, 60, 475-491. [PubMed]

104. Liu, Y.; Tikunov, Y.; Schouten, R.E.; Marcelis, L.F.M.; Visser, R.G.F.; Bovy, A. Anthocyanin biosynthesis and degradation mechanisms in Solanaceous vegetables: A review. Front. Chem. 2018, 6, 52. [CrossRef]

105. Docimo, T.; Francese, G.; Ruggiero, A.; Batelli, G.; de Palma, M.; Bassolino, L.; Toppino, L.; Rotino, G.L.; Mennella, G.; Tucci, M. phenylpropanoids accumulation in eggplant fruit: Characterization of biosynthetic genes and regulation by a MYB transcription factor. Front. Plant Sci. 2015, 6, 1233. [CrossRef] 
106. Moglia, A.; Florio, F.E.; Iacopino, S.; Guerrieri, A.; Milani, A.M.; Comino, C.; Barchi, L.; Marengo, A.; Cagliero, C.; Rubiolo, P.; et al. Identification of a new R3 MYB type repressor and functional characterization of the members of the MBW transcriptional complex involved in anthocyanin biosynthesis in eggplant (S. melongena L.). PLoS ONE 2020, 15, e0232986. [CrossRef]

107. Zhang, Y.; Hu, Z.; Chu, G.; Huang, C.; Tian, S.; Zhao, Z.; Chen, G. Anthocyanin accumulation and molecular analysis of anthocyanin biosynthesis-associated genes in eggplant (Solanum melongena L.). J. Agric. Food Chem. 2014, 62, 2906-2912. [CrossRef] [PubMed]

108. Xiao, X.O.; Lin, W.Q.; Li, K.; Feng, X.F.; Jin, H.; Zou, H. Transcriptome analyses reveal anthocyanin biosynthesis in eggplants. PeerJ Prepr. 2018, 6, e27289v1.

109. Saito, K.; Kobayashi, M.; Gong, Z.; Tanaka, Y.; Yamazaki, M. Direct evidence for anthocyanidin synthase as a 2-oxoglutarate-dependent oxygenase: Molecular cloning and functional expression of cDNA from a red forma of Perilla frutescens. Plant J. 1999, 17, 181-189. [CrossRef]

110. Hirsch, C.D.; Springer, N.M. Transposable element influences on gene expression in plants. Biochim. Et Biophys. Acta-Gene Regul. Mech. 2017, 1860, 157-165. [CrossRef]

111. Williams, M.E.; Torabinejad, J.; Cohick, E.; Parker, K.; Drake, E.J.; Thompson, J.E.; Hortter, M.; DeWald, D.B. Mutations in the Arabidopsis phosphoinositide phosphatase gene SAC9 lead to overaccumulation of PtdIns(4,5)P2 and constitutive expression of the stress-response pathway. Plant Physiol. 2005, 138, 686-700. [CrossRef] [PubMed]

112. Yoo, J.; Ho Shin, D.; Cho, M.-H.; Kim, T.-L.; Hee Bhoo, S.; Hahn, T.-R. An ankyrin repeat protein is involved in anthocyanin biosynthesis in Arabidopsis. Physiol. Plant. 2011, 142, 314-325. [CrossRef] [PubMed]

113. Shen, X.F.; Zhao, Y.; Jiang, J.P.; Guan, W.X.; Du, J.F. Phosphatase Wip1 in immunity: An overview and update. Front. Immunol. 2017, 8, 8. [CrossRef] [PubMed]

114. Luo, H.; Li, W.; Zhang, X.; Deng, S.; Xu, Q.; Hou, T.; Pang, X.; Zhang, Z.; Zhang, X. In planta high levels of hydrolysable tannins inhibit peroxidase mediated anthocyanin degradation and maintain abaxially red leaves of Excoecaria Cochinchinensis. BMC Plant Biol. 2019, 19, 1-20. [CrossRef]

115. Fang, F.; Zhang, X.L.; Luo, H.H.; Zhou, J.J.; Gong, Y.H.; Li, W.J.; Shi, Z.W.; He, Q.; Wu, Q.; Li, L.; et al. An intracellular Laccase is responsible for epicatechin-mediated Anthocyanin degradation in litchi fruit Pericarp. Plant Physiol. 2015, 169, 2391-2408. [CrossRef] [PubMed]

116. Zipor, G.; Duarte, P.; Carqueijeiro, I.; Shahar, L.; Ovadia, R.; Teper-Bamnolker, P.; Eshel, D.; Levin, Y.; Doron-Faigenboim, A.; Sottomayor, M.; et al. In planta anthocyanin degradation by a vacuolar class III peroxidase in Brunfelsia calycina flowers. New Phytol. 2015, 205, 653-665. [CrossRef]

117. Sytar, O.; Zivcak, M.; Bruckova, K.; Brestic, M.; Hemmerich, I.; Rauh, C.; Simko, I. Shift in accumulation of flavonoids and phenolic acids in lettuce attributable to changes in ultraviolet radiation and temperature. Sci. Hortic. 2018, 239, 193-204. [CrossRef]

118. Ino, I.; Yamaguchi, M.A. Acetyl-coenzyme A: Anthocyanidin 3-glucoside acetyltransferase from flowers of Zinnia elegans. Phytochemistry 1993. [CrossRef]

119. Chong, J.; Baltz, R.; Schmitt, C.; Beffa, R.; Fritig, B.; Saindrenan, P. Downregulation of a pathogen-responsive tobacco UDP-Glc:phenylpropanoid glucosyltransferase reduces scopoletin glucoside accumulation, enhances oxidative stress, and weakens virus resistance. Plant Cell 2002. [CrossRef]

120. Tanaka, Y.; Brugliera, F. Flower colour and cytochromes P450. Philos. Trans. R. Soc. B Biol. Sci. 2013, 368, 20120432. [CrossRef]

121. Su, V.; Hsu, B.D. Transient expression of the cytochrome p450 CYP78A2 enhances anthocyanin production in flowers. Plant Mol. Biol. Report. 2010. [CrossRef]

122. Höll, J.; Vannozzi, A.; Czemmel, S.; Donofrio, C.; Walker, A.R.; Rausch, T.; Lucchin, M.; Boss, P.K.; Dry, I.B.; Bogsa, J. The R2R3-MYB transcription factors MYB14 and MYB15 regulate stilbene biosynthesis in Vitis vinifera. Plant Cell 2013. [CrossRef]

123. Ali, M.B.; McNear, D.H. Induced transcriptional profiling of phenylpropanoid pathway genes increased flavonoid and lignin content in Arabidopsis leaves in response to microbial products. BMC Plant Biol. 2014. [CrossRef] [PubMed] 
124. Albert, N.W. Subspecialization of R2R3-MYB repressors for anthocyanin and proanthocyanidin regulation in forage legumes. Front. Plant Sci. 2015. [CrossRef] [PubMed]

125. Zhang, X.; Gou, M.; Liu, C.J. Arabidopsis kelch repeat F-Box proteins regulate phenylpropanoid biosynthesis via controlling the turnover of phenylalanine ammonia-lyase. Plant Cell 2013. [CrossRef]

(C) 2020 by the authors. Licensee MDPI, Basel, Switzerland. This article is an open access article distributed under the terms and conditions of the Creative Commons Attribution (CC BY) license (http://creativecommons.org/licenses/by/4.0/). 